\title{
Spring quality assessment and effects on the health of inhabitants of Santa Sub-Division, North West Region, Cameroon
}

\author{
Iren Kahnji NJOYIM ${ }^{1}$, Lucas KENGNI ${ }^{1 *}$, Jules TAMEN ${ }^{1}$, Tita Margaret AWAH ${ }^{2}$ and \\ Njoyim Estella Buleng TAMUNGANG ${ }^{3}$
}

\author{
${ }^{I}$ Department of Earth Science, Faculty of Science, University of Dschang, P.O. Box 67, Dschang, Cameroon. \\ ${ }^{2}$ Department of Biology, Higher Teacher Training College, University of Bamenda, Cameroon. \\ ${ }^{3}$ Department of Chemistry, Higher Teacher Training College, University of Bamenda, Cameroon. \\ "Corresponding author; E-mail: lkengni@yahoo.fr
}

\begin{abstract}
Lack of published data on the petrography and quality of drinkable water sources in Santa Sub Division renders the water quality in the locality doubtful. This research work was therefore aimed at evaluating the quality of spring water and its effects on human health since they depend on springs as their major source of drinking water. This work examines some petrographic, physicochemical and bacteriological properties and anthropogenic activities on water sources. Rock and water samples were collected from Mbei, Mbu, Njong and Santa Akum localities and analyzed using standard methods. Petrographic studies revealed three rock types: basalts, trachytes, and rhyolites. Organoleptic and physicochemical parameters fell within WHO limits indicating no contamination except for iron. Water facies were $\mathrm{HCO}_{3}-\mathrm{CO}_{3}-\mathrm{Cl}, \mathrm{Ca}-\mathrm{Na}-\mathrm{K}, \mathrm{SO}_{4}-\mathrm{Ca}-\mathrm{Mg}$ and $\mathrm{HCO}_{3}-\mathrm{Ca}-\mathrm{Mg}$ while the major ions were $\mathrm{HCO}_{3}^{-}, \mathrm{K}^{+}, \mathrm{Ca}^{2+}$ and $\mathrm{Mg}^{2+}$ with Total dissolved solids having the highest concentration (147.6 for both seasons), suggesting an influence of rock silicate weathering and ion exchange processes. However, pathogens were present in all the springs thus prevalence of waterborne diseases in Santa. This poor water quality was likely due to poor hygiene and anthropogenic activities. This water may lead to health implication to the community.
\end{abstract}

(c) 2019 International Formulae Group. All rights reserved.

Keywords: Santa Sub-division, spring quality, bacteria, contamination, petrography, anthropogenic.

\section{INTRODUCTION}

The quality of drinking water impacts public health and therefore, effective monitoring and a comprehensive assessment of public drinking water systems are crucial to protect the wellbeing of the public and allow the implementation of a preventive approach to manage drinking water quality ( $\mathrm{Li}$ et al., 2009). Lack of access to clean water, improved sanitation and adequate hygiene (WASH) are major contributors to the burden of several infectious diseases (Strunz et al., 2014; Stocks et al., 2014). Also, pesticides and fertilizers are considered as one of the primary pollutants in water because they are harmful to organisms even at low concentrations and many of them have been classified as hazardous pollutants because of their potential hazards to human health. However, the persistent action of sodium hypochlorite preserves the quality of water against microbial contamination (Aminata et 
al., 2018). The use of water sources for domestic activities increases every day especially due to pollution (Germain et al., 2019). The composition of water depends on the environment in which the water sources are found (Mfonka et al., 2015). The access to good drinking water is an indispensable condition for health which is also linked to sanitary protection (Njoyim et al., 2016). So, the lack of good quality water in Santa may affects the health of the community and their culture and development. Poor water quality is an economic and health problem and a human right and environmental issue according to the United Nations Environment Program/Global Environment Monitoring System (2006). Therefore, water quality is important and needs to be determined before local communities can adopt a water source for domestic use or devise a treatment plan for the water used. The study of the quality of spring water and surface water is of growing importance worldwide (Provencher, 2010) as these sources of water are more readily accessible than safer groundwater. The Cameroon Water and Utilities Corporation (Cam Water) created in 2005 to be in charge of providing potable water to communities is however limited to meet the demands of the growing urban communities thus neglected the ever growing rural community too. Drinking water access is $72 \%$ in urban areas and barely $28 \%$ in rural areas, and some of the people in these communities are obliged to fetch water from alternative sources such as springs, streams, rivers, wells, and boreholes (INS, 2008) whose quality is unknown. During the rainy season, the inhabitants of rural communities depend more on rainwater with annual rainfall amount between 2000 $3000 \mathrm{~mm}$ in Santa (Santa council, 2015).and in the dry season, the inhabitants rely more on spring water that is seldom treated which may affect the health of the inhabitants. Additionally, it is necessary that the chemical content of the water be determined in order to elucidate surface and subsurface chemical evolution and the main processes responsible for water mineralization. Aiuppa et al. (2003) suggested that the geochemical evolution and mineralization of water-rock is useful to assess the factors that influence water quality.
Therefore the objectives of this study was (1) to characterize the water-rock interaction chemical evolution of water sources and water mineralization in the Santa Sub-division and (2) to assess the physicochemical and bacteriological aspects of the water sources to elucidate anthropogenic contamination and (3) to relate water borne diseases data from the hospital and questionnaires to the health of the inhabitants. The results from this study could be used to assess the relationship between community health and water consumption for the inhabitants of Santa Mbei, Mbu, Njong and Santa-Akum villages in the Santa subdivision.

\section{MATERIALS AND METHODS Site Description}

Santa sub-division is located between latitudes $5^{\circ} 55^{\prime}$ and $5^{\circ} 67^{\prime} \mathrm{N}$ and longitude $10^{\circ} 15^{\prime}$ and $10^{\circ} 22^{\prime} \mathrm{E}$, at an altitude of $1400 \mathrm{~m}$ to $1700 \mathrm{~m}$ (Figure 1). The annual rainfall ranges between 2000 to $3000 \mathrm{~mm} \mathrm{y}^{-1}$, with an annual average temperature recorded at the Santa Agricultural Post (SAP, 2013) of $19{ }^{\circ} \mathrm{C}$. The Santa sub-division is generally windy and cloudy (SAP, 2013). The surface area is about 534 square $\mathrm{km}$, occupied by a population of about 57477 inhabitants (SAP, 2013). The population density is about 108 inhabitants per $\mathrm{km}^{2}$. The study area is mountainous and is located along the Cameroon Volcanic Line. The area comprises a mixture of plateaus and plains with the highest point being Mount Lefo at $2545 \mathrm{~m}$, located in Awing. Also, the landscape is covered mainly with grasses and hinges of forest along the gentle slopes and narrow valleys. The climate of the study area is characterized by two distinct seasons: the dry season which spans from December to March and the rainy season which spans from March to November (Figure 2). The nights are generally cold with an average temperature of $17-18{ }^{\circ} \mathrm{C}$, while the days are hot with an average temperature of $19-25{ }^{\circ} \mathrm{C}$ (SAP, 2013).

There are three main types of soils in the study area: Penevoluted ferralitic soils found mostly in the low-lying areas especially in Santa Town, Santa-Akum and Njong; Orthic soils found in the highlands of Mbu; 
while the Mbei areas are dominated by the Aliatic and Penevoluted ferralitic red soils (Magha, 2003). Intensive agriculture is practiced by the inhabitants in the lowlands with fertile soils that accumulate nutrients washed from uphill soils. Crops like Irish potatoes, cabbage, carrots and spices are grown in the valleys (Magha, 2003). Intensive cattle breeding occurs mostly in the hilly areas and at times along the valleys.

\section{Sampling and field methods}

Fresh bulk rocks were collected from the field from 11 localities (Figure 3) and the rock samples were used to prepare thin sections using classical methods. The thin section slides were observed under the microscope and the mineral and rock types were identified and described.

Water samples were collected in January 2015 during the dry season and in July 2015 during the rainy season (Figure 7). Sampling sites were selected based on factors such as water use, agricultural activities and absence of pipe borne water in the locality.

Selected sites were Njong-Mbumatoh spring (S1), at $05^{\circ} 49^{\prime} 08.4^{\prime \prime} \mathrm{N}$ and $10^{\circ} 10^{\prime} 34.0^{\prime \prime}$ E with an elevation of $1904 \mathrm{~m}$; the Mbei spring (S2), at $05^{\circ} 48^{\prime} 13.7^{\prime \prime} \mathrm{N}$ and $10^{\circ} 09^{\prime} 15.5^{\prime \prime}$ $\mathrm{E}$ with an elevation of $1760 \mathrm{~m}$; the $\mathrm{Mbu}$ spring (S3), at $05^{\circ} 47^{\prime} 13.6^{\prime \prime} \mathrm{N}$ and $10^{\circ} 09^{\prime} 28.0^{\prime \prime}$ E with an elevation of $1710 \mathrm{~m}$; the Ngabshi spring (S4), at $05^{\circ} 47^{\prime} 35.3^{\prime \prime} \mathrm{N}$ and $10^{\circ} 09^{\prime} 45.9^{\prime \prime}$ E with an elevation of $1728 \mathrm{~m}$; the NjongMbawezang spring (S5), at $05^{\circ} 48^{\prime} 28.5^{\prime \prime} \mathrm{N}$ and $10^{\circ} 10^{\prime} 14.4^{\prime \prime} \mathrm{E}$ with an elevation of $1778 \mathrm{~m}$; and the Nkiedor spring (S6), at $05^{\circ} 47^{\prime} 40.4^{\prime \prime} \mathrm{N}$ and $10^{\circ} 09^{\prime} 57.7^{\prime \prime} \mathrm{E}$ with an elevation of $1709 \mathrm{~m}$ (Figure 7). All the samples were collected on the same day in order to better evaluate the quality of the water sources (Figure 13).

At each sampling site, water temperature, $\mathrm{pH}$, total dissolved solids and electrical conductivity were measured in-situ using a portable multi-parameter probe calibrated with standard solutions. Three samples were collected in pre-washed and sterilized 1.5 liters plastic bottles. The containers and caps of plastic bottles were rinsed three times with water to be sampled before collecting the required sample volume. High purity $\mathrm{HNO}_{3}^{-}$was added to one of the containers to stabilize the sample for measurements of cations. Water samples for bacteriological tests were preserved on ice to maintain the temperature at $4{ }^{\circ} \mathrm{C}$ to minimize physicochemical changes. The samples were then transported to the laboratory where they were stored and refrigerated until analyses were conducted. Flow rates were also determined through Volume/Time measurements.

\section{Petrographic analysis}

Thin sections of rocks were prepared from bulk rocks from the field in the laboratory of Institut de Recherche Géologique Minières (IRGM) using classical methods.

\section{Organoleptic and physicochemical analyses}

Organoleptic parameters were observed with the five senses for gross appearance and also for offensive odor through the subjective organoleptic assessment. One of the characteristics was the color and state of floating of particles in some of the spring samples (Mbumatoh and Nkidor) which had floating debris during sampling in both seasons. The turbidity of water samples was measured using a turbidimeter (DRT, 100B, MF scientific, Inc). The chloride concentration of the samples was measured by the argentometric method (silver nitrate titration). Since nitrate-nitrogen is unstable and volatile, it was determined by Raleigh Atomic Absorption Spectrophotometry. Heavy metals ( $\mathrm{Zn}, \mathrm{As}, \mathrm{Cu}, \mathrm{Pb}, \mathrm{Mn}$, and $\mathrm{Fe}$ ) were measured using Atomic Absorption Spectrophotometry (AAS). The $\mathrm{CO}_{3}^{2-,}$ and $\mathrm{HCO}_{3}^{-}$ions were determined by titrimetric techniques. Cations such as $\mathrm{Ca}^{2+}$ and $\mathrm{Mg}^{2+}$ were determined by complexometric titration, while $\mathrm{K}^{+}$and $\mathrm{Na}^{+}$were measured by flame photometry. The $\mathrm{PO}_{4}{ }^{3-}$ was determined by spectrometric Ultraviolet method and the $\mathrm{SO}_{4}{ }^{2-}$ by the gravimetric method.

\section{Bacteriological analysis}

According to Cheesbrough (2000) the multi-tube fermentation technique (the most probable technique of diluted sample) and membrane filter technique were used for bacteria analysis. An oven at $160{ }^{\circ} \mathrm{C}$ was used 
to sterilize glassware for one hour. The specific culture media for the bacteria were measured and introduced in sterilized beakers containing $300 \mathrm{~mL}$ of distilled water and mixed. The mixtures were then sterilized at $120{ }^{\circ} \mathrm{C}$ in an autoclave for 15 minutes. After cooling, the various culture media were put in Petri dishes containing $1 \mathrm{~mL}$ of sample and mixed until coagulation. The sample mixtures were incubated under a Bunsen burner at 44 ${ }^{\circ} \mathrm{C}$ for $24 \mathrm{~h}$, after which the number of colonies of specific microbes were counted.

\section{Data treatment}

The Hill-Piper's (AM 1953) charts were used to represent the chemical composition of natural waters and to interpret the genesis of the chemical character of the springs. Total dissolved solids (TDS) is expressed as the sum of major inorganic species $\left(\mathrm{Na}^{+}, \mathrm{K}^{+}, \mathrm{Ca}^{2+}, \mathrm{Mg}^{2+}, \mathrm{Fe}^{2+}, \mathrm{SiO}_{2}\right.$, $\mathrm{HCO}_{3}^{-}, \mathrm{Cl}^{-}, \mathrm{NO}_{3}^{-}, \mathrm{SO}_{4}^{2-}$ and $\mathrm{PO}_{4}^{3-}$ ). Piper plots were constructed for cation and anion facies to determine the chemical facies and ionic evolution.

Paired sample test/correlation was carried out using SPSS statistics (Spearman correlation) where ( $\mathrm{P}<0.01) 99 \%$ confidence interval **, $(\mathrm{P}<0.05) 95 \%$ confidence interval *, $(\mathrm{P}>0.05)$ below $95 \%$ confidence interval and not significant, $* *=$ highly significant, $*$ significant and $\mathrm{NS}=\mathrm{Not}$ significant.

The Base Exchange Index values (BEI) of the springs were calculated according to Schoeller (1962) as BEI $=\mathrm{Cl}-(\mathrm{Na}+\mathrm{K}) / \mathrm{Cl}$.
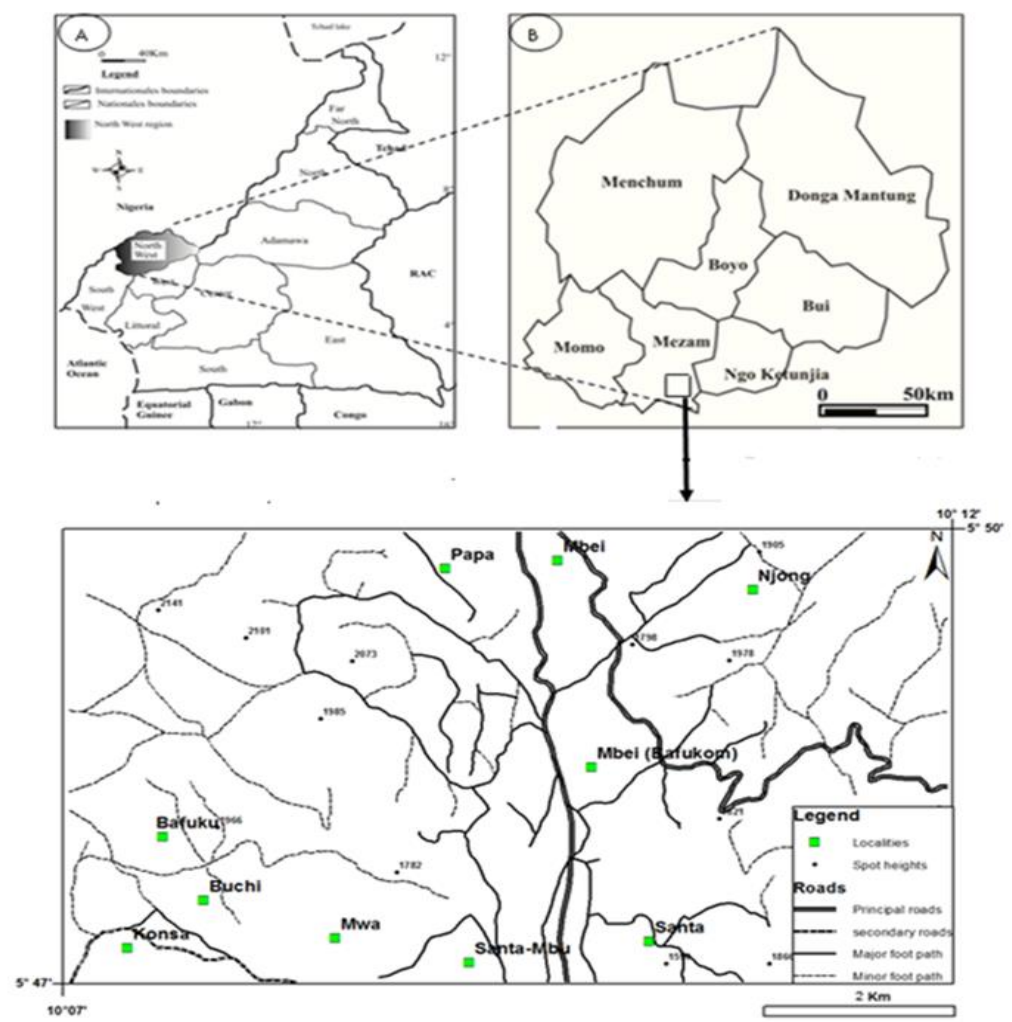

Figure 1: Location of the study area showing topography, towns, rivers and roads. Also shown in the insert are Cameroon and the divisions in the North West Province of Cameroon where Santa sub-division is located. 


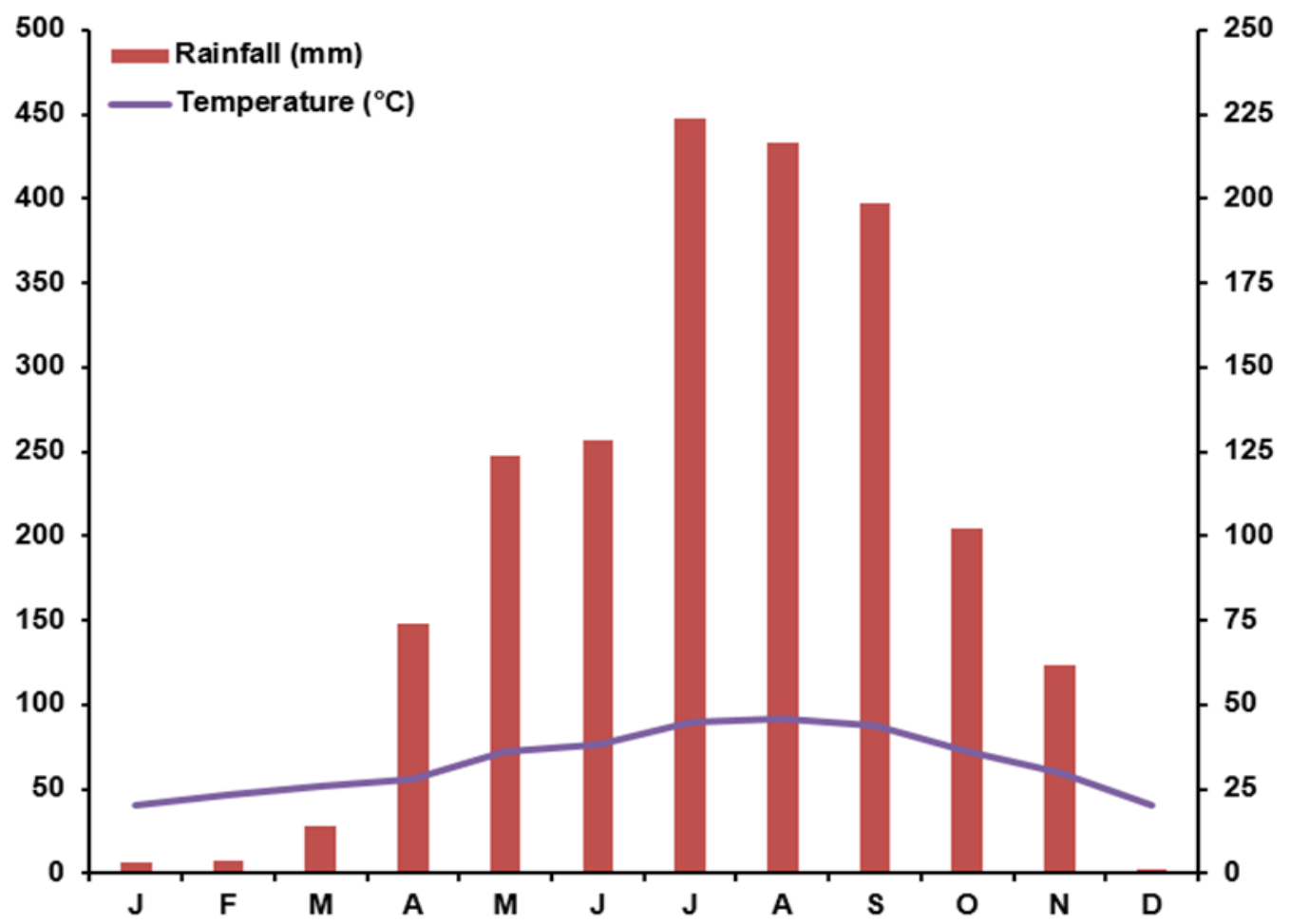

Figure 2: Mean monthly temperature and rainfall in Santa for 2013 (SAP, 2013).

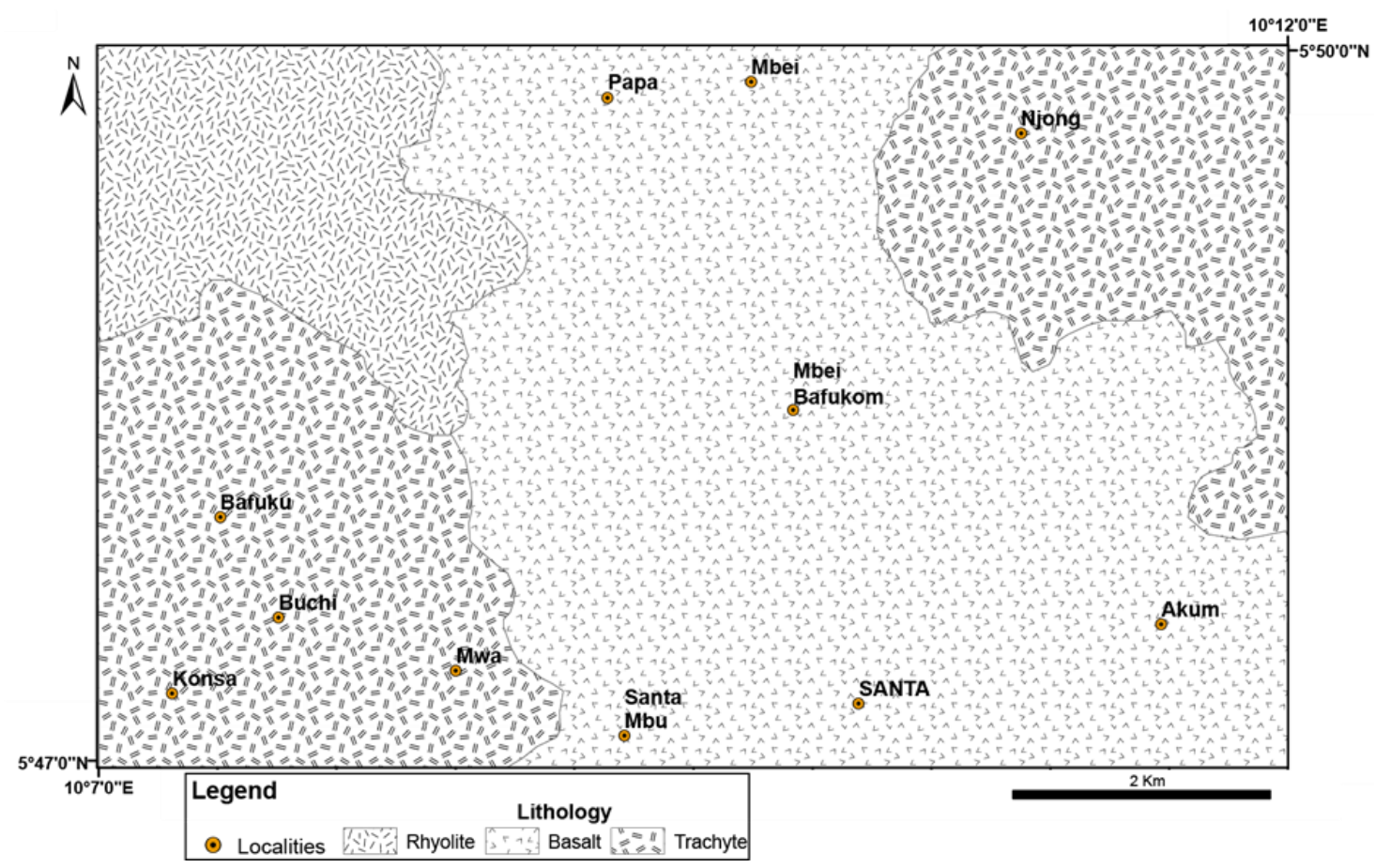

Figure 3: Geological map of the study area showing localities sampled for rocks. 


\section{RESULTS \\ Petrographic analysis}

The petrographic studies showed that rocks in the study area are mainly rhyolitic, trachytic and basaltic as observed in thin sections (Figure 3). Macroscopically rocks outcrop as boulders or blocks in the study area. Basalts were subdivided into: Olivine basalts which showed microlitic microphenocryst of olivine, porphyritic textures and aphyritic to sub-aphyritic textures of some pyroxenes while Alkali olivine basalts showed more of felsic minerals. The groundmass of both basalts is made up of 30 vol \% of microlites of plagioclase and microcrystals of oxide, scattered within the ground mass and olivine and clinopyroxene. Rhyolites were mostly made up of orthoclase with the ground mass composed of quartz. The oxides were the least abundant $(5 \mathrm{vol} \%)$ and form xenomorphic granules of about $0.2 \mathrm{~mm}$ in diameter. The rock matrix was essentially made up of quartz, alkaline feldspars and plagioclase in the form of grains. Trachytes were made up of elongated crystals of plagioclase with sanidine crystals showing Carlsbad twinning and also Clinopyroxene constituted about $5 \%$ of the rock and occurred mostly in the matrix. Their sizes range from microcrystals to phenocrysts $(0.25 \times 0.5 \mathrm{~mm}-1.5 \times 2.5 \mathrm{~mm}$ ) (Figure 4, 5 and $6)$.

\section{Organoleptic and physicochemical analysis}

Based on Organoleptic analysis, the water sources were colourless and odourless, with clean and clear appearance for both seasons except for the Mbumatoh and Nkiedor springs which showed a brown color in July.

The flow rates of the different springs ranged from $19-54.6 \mathrm{~V} / \mathrm{t}$ in the dry season and $2.54-19.30 \mathrm{~V} / \mathrm{t}$ in the rainy season (Table 1). Physico-chemical parameters determined for the springs are summarized in Tables 2 to 5. Results of $\mathrm{pH}$, Temperature, Electrical conductivity and Total dissolved solids are presented in Table 2 . The $\mathrm{pH}$ values ranged from 5.1 to 6.4 in the dry season and 6.8 to 7.4 during the rainy season falling slightly lower on the acidic side as compared to the WHO standard for $\mathrm{pH}$ which ranges from $6.5-9$. Temperature values ranged from 18.8 - 20.4 for both seasons which was slightly lower than the room temperature (Figure 2). The Electrical conductivity (EC) of the springs ranged from $10.8 \mu \mathrm{S} / \mathrm{cm}$ to 99.1 $\mu \mathrm{S} / \mathrm{cm}$ while Total Dissolved solid (TDS) values ranged from $12-77.3 \mathrm{mg} / \mathrm{L}$ and both values fell below WHO specifications. Figure 13 illustrates the various springs and their sources.

\section{Cations and anions}

The concentrations of cations were as follows: $\mathrm{K}^{+}(2.0-16.40 \mathrm{mg} / \mathrm{L}), \mathrm{Ca}^{2+}(3.61-$ $16.40 \mathrm{mg} / \mathrm{L}), \mathrm{Na}^{+}(1.02-8.25 \mathrm{mg} / \mathrm{L}), \mathrm{Mg}^{2+}$ $(1.0-20.20 \mathrm{mg} / \mathrm{L})$ and these concentrations were below the WHO limits. (Table 3). The order of abundance for cations was as follows $\mathrm{Mg}^{2+}>\mathrm{Ca}^{2+}>\mathrm{K}^{+}>\mathrm{Na}^{+}$(Figure 9).

Heavy metals were also observed in the study area. $\mathrm{Pb}^{2+}$ had values ranging from $0.01-0.05 \mathrm{mg} / \mathrm{L}, \mathrm{Mn}^{2+}(0.01-0.50 \mathrm{mg} / \mathrm{L})$, $\mathrm{As}^{2+}(0.01-0.07 \mathrm{mg} / \mathrm{L}), \mathrm{Cu}^{2+}(0.03-0.66$ $\mathrm{mg} / \mathrm{L}), \mathrm{Zn}^{2+}(0.01-0.82 \mathrm{mg} / \mathrm{L})$ and $\mathrm{Fe}^{2+}(0.20$ $-2.94 \mathrm{mg} / \mathrm{L}$ ) being the highest in the area (Table 5).

For anions, $\mathrm{HCO}_{3}^{-}$was the dominant species with concentration values ranging from 1.7 to $16.2 \mathrm{mg} / \mathrm{L}$, for The order of abundance for the rest of the anions was $\mathrm{PO}_{4}{ }^{3-}$ $(0.02-19.02 \mathrm{mg} / \mathrm{L}), \mathrm{SO}_{4}{ }^{2-}(1.34-12.01$ $\mathrm{mg} / \mathrm{L}), \mathrm{NO}_{3}{ }^{-}(1.10-7.84 \mathrm{mg} / \mathrm{L}), \mathrm{CO}_{3}{ }^{-}(2.30-$ $12.02 \mathrm{mg} / \mathrm{L}$ and $\mathrm{Cl}^{-}(0.40-8.6 \mathrm{mg} / \mathrm{L})$ (Figure 10). These values were low and fell below the WHO maximum limits of $10 \mathrm{mg} / \mathrm{L}$ and 250 $\mathrm{mg} / \mathrm{L}$ respectively (Table 4 ). The suitability of water sources in the area for drinking was determined based mainly on standards set by the W H O, 2009 and organic decay by Yidana et al. (2008).

Base Exchange index

The Base Exchange index revealed two water sources, Mbei (S2) and Mbu (S3) springs having positive values of BEI (Table 9) and four water sources, Mbumatoh (S1), Ngabshi (S4), Mbawezang (S5) and Nkiedor (S6) springs having negative values of BEI.

\section{Correlation between parameters}

Water sources showed a large significant difference with physicochemical 
parameters for both seasons. The $\mathrm{pH}$ of all the water sources was highly significantly and positively correlated with sodium $(\mathrm{r}=0.89, \mathrm{p}$ $<0.05)$, sulphate $(\mathrm{r}=0.88, \mathrm{p}<0.05)$ and nitrate $(r=0.94, p<0.05)$ content of the water sources (Table 8 ). The temperature of water sources was significant and positively correlated with sulphate $(r=0.94, p<0.05)$. The nitrate content of the water sources was highly significant and positively correlated with phosphorus $(r=0.99, p<0.05)$, maybe due to the use of fertilizers. The phosphate content was highly significant and positively correlated with the bacteria enterobacteria, Escherichia coli and Streptococcus $(\mathrm{r}=0.89$, $\mathrm{p}<0.01)$ content of the water sources.

\section{Water classification}

On the Piper diagram (Piper 1953), about $65 \%$ of the springs are $\mathrm{Na}-\mathrm{K}-\mathrm{Mg}$ water-type and the remaining $35 \%$ are of the $\mathrm{Mg}$ water type. For anion proportions about $70 \%$ of springs were of the $\mathrm{HCO}_{3}-\mathrm{Cl}$-type and $30 \%$ of the Cl-type. The water types combine on the diamond-shaped field in the $\mathrm{HCO}_{3}-\mathrm{Ca}-\mathrm{Mg}$ segment, thus the major type of water in the area is the calcium-bicarbonate $\left(\mathrm{Ca}-\mathrm{HCO}_{3}\right)$ water-type with $80 \%$ of water having this composition (Figure 8).

\section{Bacteriological analysis}

All the water sources had pathogens ranging from $00-200$ microbes $/ \mathrm{ml}$. Sample Ngabshi (S4) and Nkiedor (S6) springs fell under category C (WHO, 2008) during the rainy season, indicating a high health risk to the population and hence not fit for consumption. The other springs fell under category $\mathrm{B}$, indicating low health risk which implies that the water sources could be accepted for drinking if the sources are disinfected and equipment maintained. Enterobacteria, E.coli, and Streptococcus were present in all the spring samples in the dry and rainy seasons (Tables 6 and 7).

\section{Hospital data}

Data from Santa health district and results from questionnaires administration showed the prevalence of some water-borne diseases in the area such as diarrhea, dysentery, and typhoid. Data from the Santa District hospital indicated that adults in Mbu and Mbei villages recorded the highest no of cases of Typhoid and Dysentery prevalence respectively while Infants in Mbei village recorded the highest no of cases of Diarrhoea prevalence (Figure 11). This is confirmed by questionnaires data where Mbu and Mbei still recorded highest cases of typhoid in adults while Santa-Akum had the highest cases in infants. Njong village (Mbumatoh and Mbawezang) recorded the highest no of cases of diarrhoea in adults while the Mbei village had the highest no of cases in infants. SantaAkum village recorded the highest no of cases of dysentery in adults and infants. According to the questionnaires data, all the villages were aware of water borne diseases with highest no of infected persons from SantaAkum and Mbei followed by Mbu and Njong villages (Figure 12).

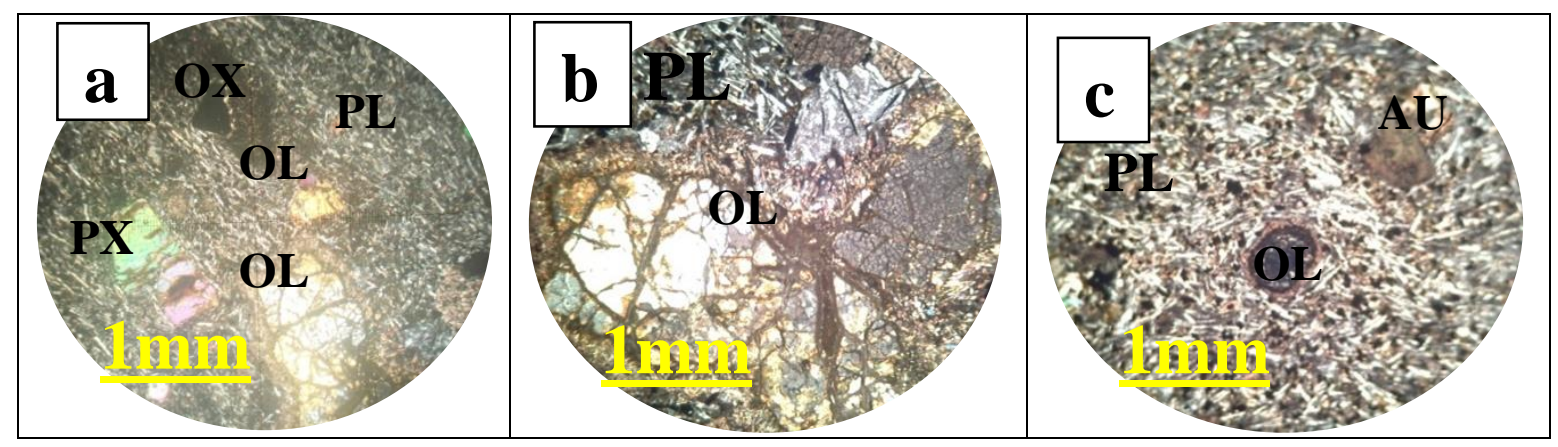

Figure 4: Thin sections of olivine alkali basalt. 


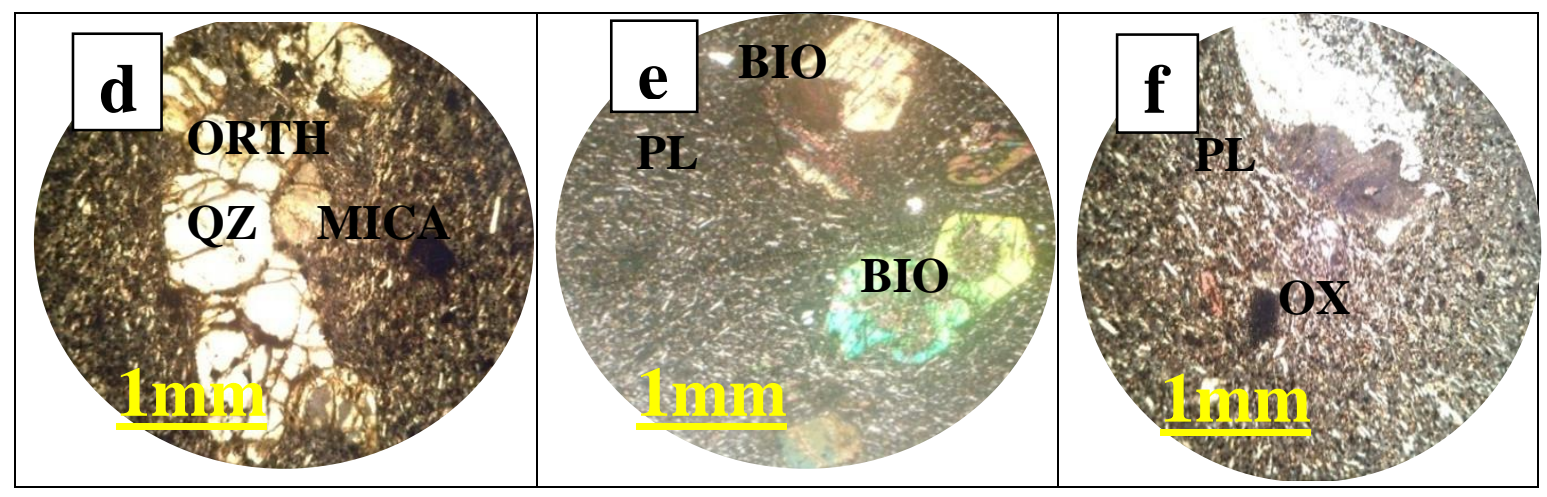

Figure 5: Thin sections of Rhyolites.

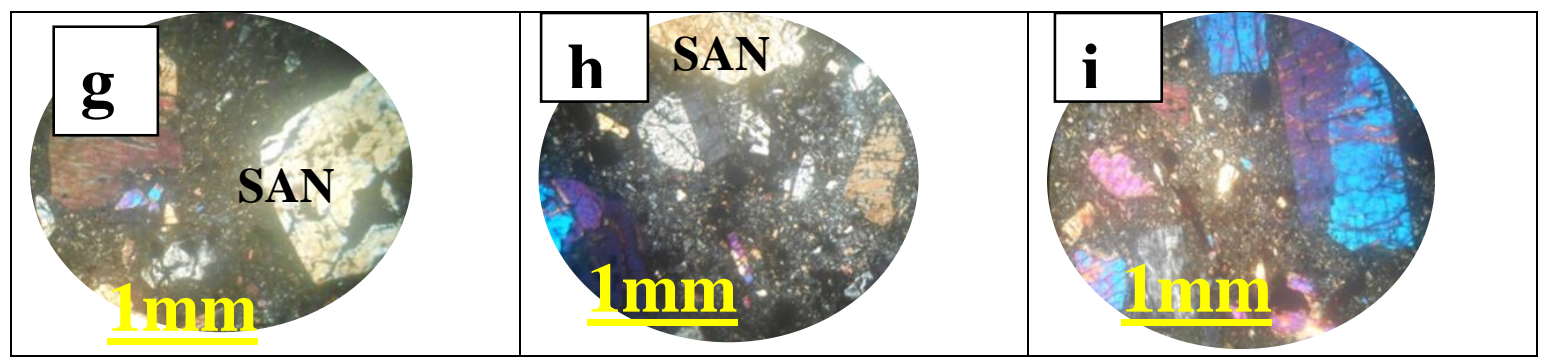

Figure 6: Thin sections of Trachytes.

Table 1: The flow rate of springs in the rainy season and dry season.

\begin{tabular}{cccccccccc}
\hline \multicolumn{4}{c}{ Rainy season } & \multicolumn{5}{c}{ Dry season } \\
\hline Sample & \multicolumn{3}{c}{ Discharge Measurement $(\mathbf{L} / \mathbf{s})$} & Samples & \multicolumn{3}{c}{ Discharge measurement (L/s) } \\
\hline & $1 \mathrm{st}$ & $2^{\text {nd }}$ & $3^{\text {rd }}$ & Average & & 1 st & $2^{\text {nd }}$ & $3^{\text {rd }}$ & Average \\
S1 & 54.00 & 53.00 & 57.00 & 54.60 & S1 & 19.30 & 18.22 & 20.34 & 19.30 \\
S2 & 54.00 & 16.00 & 15.00 & 28.30 & $\mathbf{S 2}$ & 5.31 & 5.17 & 5.49 & 5.32 \\
S3 & 54.00 & 5.200 & 4.57 & 21.30 & $\mathbf{S 3}$ & 6.20 & 5.80 & 5.57 & 5.86 \\
S4 & 54.00 & 1.80 & 1.60 & 20.00 & $\mathbf{S 4}$ & 2.61 & 2.54 & 2.47 & 2.54 \\
S5 & 54.00 & 1.38 & 1.36 & 19.00 & $\mathbf{S 5}$ & 6.30 & 5.53 & 5.62 & 5.82 \\
S6 & 54.00 & 5.04 & 5.08 & 22.00 & $\mathbf{S 6}$ & 4.45 & 4.86 & 5.00 & 4.80 \\
\hline
\end{tabular}

Table 2: Physical parameters of the samples.

\begin{tabular}{ccccccccccc}
\hline Sample & \multicolumn{2}{c}{$\mathbf{p H}$} & \multicolumn{2}{c}{$\mathbf{T}^{\circ} \mathbf{C}$} & \multicolumn{2}{c}{ E.C $(\boldsymbol{\mu s} / \mathbf{c m})$} & \multicolumn{2}{c}{ Turbidity(NTU) } & \multicolumn{2}{c}{ TDS(mg/L) } \\
\cline { 2 - 12 } & Jan & Jul & Jan & Jul & Jan & Jul & Jan & Jul & Jan & Jul \\
S1 & 5.1 & 7.4 & 19.2 & 18.8 & 22 & 21.60 & 25.2 & 19.52 & 20.2 & 15.30 \\
S2 & 5.6 & 6.7 & 20.1 & 19.7 & 17.2 & 17.1 & 14.17 & 9.76 & 14.1 & 12.00 \\
S3 & 5.8 & 6.3 & 20.2 & 20.3 & 22.2 & 18.5 & 24.4 & 24.4 & 15.2 & 13.90 \\
S4 & 5.7 & 5.8 & 20 & 19.4 & 46.6 & 54.5 & 39.4 & 30.4 & 32.6 & 38.60 \\
S5 & 5.9 & 6.4 & 19.1 & 19.5 & 22.2 & 24.3 & 34.16 & 20.52 & 24.2 & 17.20 \\
S6 & 6.4 & 7.1 & 19.8 & 20.4 & 10.8 & 99.1 & 68.32 & 70.60 & 77.3 & 70.30 \\
WHO & \multicolumn{2}{c}{$6.5-9$} & \multicolumn{1}{c}{$15-25$} & \multicolumn{2}{c}{2000} & $0.1-5$ & & 600 \\
\hline
\end{tabular}


Table 3: Chemical parameters for cations of the samples.

\begin{tabular}{ccccccccc}
\hline Sample/parameter & \multicolumn{2}{c}{$\mathbf{N a}^{+}(\mathbf{m g} / \mathbf{L})$} & \multicolumn{2}{c}{$\mathbf{K}^{+}(\mathbf{m g} / \mathbf{L})$} & \multicolumn{2}{c}{$\mathbf{C a}^{2+}(\mathbf{m g} / \mathbf{L})$} & \multicolumn{2}{c}{$\mathbf{M g}^{2+}(\mathbf{m g} / \mathbf{L})$} \\
\hline & Jan & Jul & Jan & Jul & Jan & Jul & Jan & Jul \\
S1 & 1.02 & 1.50 & 2.40 & 2.00 & 16.40 & 6.40 & 8.50 & 3.40 \\
S2 & 5.03 & 4.50 & 10.30 & 9.20 & 12.30 & 4.80 & 8.75 & 2.94 \\
S3 & 6.12 & 6.00 & 13.40 & 13.40 & 15.60 & 4.60 & 4.00 & 1.00 \\
S4 & 4.80 & 8.25 & 16.40 & 14.40 & 3.61 & 5.60 & 19.70 & 1.23 \\
S5 & 5.04 & 5.60 & 12.20 & 12.30 & 4.80 & 4.80 & 7.94 & 2.43 \\
S6 & 6.23 & 7.34 & 15.40 & 16.40 & 4.30 & 13.60 & 20.20 & 6.32 \\
WHO & \multicolumn{2}{c}{200} & \multicolumn{2}{c}{200} & & & & \\
\hline
\end{tabular}

Table 4: Chemical parameters for anions.

\begin{tabular}{|c|c|c|c|c|c|c|c|c|c|c|c|c|c|c|}
\hline \multirow[b]{2}{*}{ Sample } & \multicolumn{2}{|c|}{$\mathrm{Cl}^{-}(\mathrm{mg} / \mathrm{L})$} & \multicolumn{2}{|c|}{$\begin{array}{c}\mathrm{NO}_{3}^{-} \\
(\mathrm{mg} / \mathrm{L})\end{array}$} & \multicolumn{2}{|c|}{$\mathrm{NH}_{4}{ }^{+}(\mathrm{mg} / \mathrm{L})$} & \multicolumn{2}{|c|}{$\mathrm{SO}_{4}{ }^{2-}(\mathrm{mg} / \mathrm{L})$} & \multicolumn{2}{|c|}{$\mathrm{PO}_{4}{ }^{3-}(\mathrm{mg} / \mathrm{L})$} & \multicolumn{2}{|c|}{$\mathrm{HCO}_{3}{ }^{-}(\mathrm{mg} / \mathrm{L})$} & \multicolumn{2}{|c|}{$\begin{array}{c}\mathrm{CO}_{3}{ }^{2-} \\
(\mathrm{mg} / \mathrm{L})\end{array}$} \\
\hline & Jan & Jul & Jan & Jul & Jan & Jul & Jan & Jul & Jan & Jul & Jan & Jul & Jan & Jul \\
\hline S1 & 0.70 & 0.50 & 7.84 & 5.60 & 1.96 & 1.63 & 1.80 & 1.54 & 4.19 & 0.02 & 16.02 & 14.00 & 12.02 & 9.20 \\
\hline S2 & 8.6 & 4.2 & 1.40 & 1.10 & 0.56 & 0.23 & 8.50 & 5.03 & 19.02 & 0.02 & 13.05 & 10.50 & 3.05 & 2.50 \\
\hline S3 & 7.3 & 5.2 & 3.35 & 3.23 & 2.20 & 2.50 & 12.01 & 8.31 & 17.02 & 0.02 & 10.07 & 9.70 & 5.01 & 3.00 \\
\hline S4 & 0.90 & 0.60 & 1.12 & 1.50 & 2.01 & 1.01 & 2.10 & 4.66 & 1.08 & 0.05 & 1.07 & 1.07 & 4.30 & 2.30 \\
\hline S5 & 1.20 & 0.40 & 4.76 & 3.60 & 2.24 & 2.60 & 1.22 & 2.46 & 2.69 & 0.02 & 1.14 & 1.14 & 5.20 & 4.20 \\
\hline $\begin{array}{c}\text { S6 } \\
\text { WHO }\end{array}$ & 5.3 & 3.1 & 6.16 & 6.10 & 1.68 & 2.54 & 7.04 & 1.34 & 1.03 & 0.09 & 5.3 & 4.7 & 6.50 & 5.50 \\
\hline Limits & \multicolumn{2}{|c|}{250} & \multicolumn{2}{|c|}{45} & \multicolumn{2}{|c|}{30} & \multicolumn{2}{|c|}{250} & \multicolumn{2}{|c|}{$\leq 5$} & \multicolumn{2}{|c|}{1000} & \multicolumn{2}{|c|}{1000} \\
\hline
\end{tabular}

Table 5: Chemical parameters for Heavy metals.

\begin{tabular}{|c|c|c|c|c|c|c|c|c|c|c|c|c|}
\hline \multirow{2}{*}{$\begin{array}{c}\text { Sample } \\
\text { /parameter }\end{array}$} & \multicolumn{2}{|c|}{$\mathrm{Fe}^{2+}(\mathrm{mg} / \mathrm{L})$} & \multicolumn{2}{|c|}{$\mathrm{Zn}^{2+}(\mathrm{mg} / \mathrm{L})$} & \multicolumn{2}{|c|}{$\mathrm{Cu}^{2+}(\mathrm{mg} / \mathrm{L})$} & \multicolumn{2}{|c|}{$\mathrm{As}^{2+}(\mathrm{mg} / \mathrm{L})$} & \multicolumn{2}{|c|}{$\mathrm{Mn}^{2+}(\mathrm{mg} / \mathrm{L})$} & \multicolumn{2}{|c|}{$\mathrm{Pb}^{2+}(\mathrm{mg} / \mathrm{L})$} \\
\hline & Jan & Jul & Jan & Jul & Jan & Jul & Jan & Jul & Jan & Jul & Jan & Jul \\
\hline S1 & 1.20 & 1.60 & 0.82 & 0.07 & 0.38 & 0.22 & 0.07 & 0.03 & 0.28 & 0.10 & 0.02 & 0.01 \\
\hline S2 & 1.20 & 2.94 & 0.06 & 0.04 & 0.42 & 0.26 & 0.03 & 0.02 & 0.05 & 0.14 & 0.02 & 0.01 \\
\hline S3 & 1.20 & 1.30 & 0.72 & 0.50 & 0.36 & 0.20 & 0.02 & 0.02 & 0.33 & 0.14 & 0.05 & 0.03 \\
\hline S4 & 1.24 & 0.04 & 0.02 & 0.01 & 0.36 & 0.25 & 0.02 & 0.01 & 0.36 & 0.23 & 0.03 & 0.02 \\
\hline S5 & 1.21 & 0.20 & 0.60 & 0.38 & 0.04 & 0.03 & 0.04 & 0.02 & 0.50 & 0.33 & 0.03 & 0.03 \\
\hline S6 & 0.09 & 2.10 & 0.53 & 0.35 & 0.66 & 0.45 & 0.02 & 0.03 & 0.11 & 0.01 & 0.2 & 0.01 \\
\hline WHO & \multicolumn{2}{|c|}{0.3} & \multicolumn{2}{|c|}{3.0} & \multicolumn{2}{|c|}{20} & \multicolumn{2}{|c|}{20} & \multicolumn{2}{|c|}{0.06} & \multicolumn{2}{|c|}{0.05} \\
\hline
\end{tabular}


Table 6: Specific microbes Isolated.

\begin{tabular}{cccccccccccccc}
\hline & \multicolumn{1}{c}{ Enterobacteria } & \multicolumn{2}{c}{ Esch-coli } & \multicolumn{3}{c}{ Streptococcus } & \multicolumn{2}{c}{ Salmonella } & \multicolumn{2}{c}{ Shigella } & \multicolumn{3}{c}{ Staphylococcus } \\
\cline { 2 - 15 } Sample & Jan & July & Jan & July & Jan & July & Jan & July & Jan & July & Jan & July \\
S1 & 75 & 100 & 50 & 50 & 30 & 20 & 10 & 30 & 0.00 & 10 & 0.00 & 10 \\
S2 & 100 & 50 & 60 & 10 & 100 & 50 & 25 & 0.05 & 0.00 & 0.03 & 10 & 05 \\
S3 & 150 & 50 & 75 & 20 & 75 & 05 & 05 & 0.04 & 0.00 & 0.02 & 0.00 & 0.06 \\
S4 & 150 & 100 & 100 & 10 & 100 & 0.00 & 05 & 0.01 & 0.00 & 0.00 & 20 & 10 \\
S5 & 100 & 100 & 50 & 50 & 100 & 50 & 15 & 10 & 0.00 & 0.00 & 0.00 & 0.00 \\
S6 & 200 & 100 & 75 & 10 & 200 & 50 & 01 & 0.00 & 0.00 & 0.00 & 10 & 10 \\
WHO & 00 & & & & & & & & & & & \\
\hline
\end{tabular}

Table 7: Most Probable Number (MPN).

\begin{tabular}{|c|c|c|c|c|c|c|c|c|c|c|}
\hline \multirow{3}{*}{$\begin{array}{c}\begin{array}{c}\text { Volume of sample in } \\
\text { each bottle }\end{array} \\
\begin{array}{c}\text { Number of bottles } \\
\text { used }\end{array}\end{array}$} & \multicolumn{2}{|c|}{$50 \mathrm{ml}$} & \multicolumn{2}{|c|}{$10 \mathrm{ml}$} & \multicolumn{2}{|c|}{$1 \mathrm{ml}$} & \multicolumn{4}{|c|}{$\begin{array}{c}\text { Most Probable Number of coliforms in } 100 \mathrm{~m} \\
\text { of the original water }\end{array}$} \\
\hline & \multicolumn{2}{|c|}{1} & \multicolumn{2}{|c|}{5} & \multicolumn{2}{|c|}{5} & \multicolumn{2}{|c|}{ Mean count } & \multicolumn{2}{|c|}{ Category } \\
\hline & Jan & Jul & Jan & Jul & Jan & Jul & Jan & Jul & Jan & Jul \\
\hline S1 & 1 & 1 & 1 & 1 & 2 & 1 & 5 & 3 & $\mathrm{~B}$ & $\mathrm{~B}$ \\
\hline S2 & 1 & 1 & 1 & 2 & 0 & 1 & 3 & 7 & B & $\mathrm{B}$ \\
\hline S3 & 0 & 1 & 2 & 1 & 1 & 1 & 3 & 5 & B & $\mathrm{B}$ \\
\hline S4 & 0 & 1 & 3 & 4 & 1 & 2 & 5 & 20 & B & $\mathrm{C}$ \\
\hline S5 & 0 & 1 & 1 & 1 & 2 & 2 & 4 & 7 & B & B \\
\hline S6 & 1 & 1 & 0 & 4 & 1 & 1 & 4 & 7 & B & $\mathrm{C}$ \\
\hline WHO & 00 & & & & & & & & & \\
\hline
\end{tabular}

Table 8: Paired samples correlated between water samples.

\begin{tabular}{|c|c|c|c|c|c|c|c|c|c|c|c|}
\hline Properties & $\begin{array}{c}\mathbf{p H} \\
\mathrm{Na}^{+}\end{array}$ & $\underset{\mathrm{SO}_{4}^{2}}{\mathbf{p H}}$ & $\begin{array}{c}\mathbf{p H} \\
\mathrm{NO}_{3}\end{array}$ & $\begin{array}{l}\mathrm{NO3}^{-} \\
\mathrm{PO}_{4}{ }^{3-}\end{array}$ & $\begin{array}{l}\mathrm{CO}_{3} \\
\mathrm{NO}_{3}\end{array}$ & $\begin{array}{c}\mathrm{CO}_{3}{ }^{-} \\
\mathrm{K}^{+}\end{array}$ & $\underset{\mathbf{M g}^{2+}}{\mathbf{p H}}$ & $\begin{array}{c}\mathbf{T}^{\circ} \mathbf{C} \\
\mathbf{C l}^{-}\end{array}$ & $\begin{array}{l}\mathbf{T}^{\circ} \mathbf{C} \\
\mathbf{C a}^{2+}\end{array}$ & $\begin{array}{l}\mathrm{T}^{\circ} \mathrm{C} \\
\mathrm{SO}_{4}{ }^{2-}\end{array}$ & $\begin{array}{c}\mathrm{PO}_{4}{ }^{3-}- \\
\mathbf{B a c}\end{array}$ \\
\hline \multirow[t]{2}{*}{ r-value } & 0.886 & 0.883 & 0,943 & 0.998 & 0.886 & 0.886 & 0.886 & 0.894 & 1.000 & 0.943 & 0.892 \\
\hline & \multicolumn{2}{|c|}{$\mathrm{S}$} & $*$ & $* *$ & & & NS & & & $*$ & $*$ \\
\hline
\end{tabular}

(P < 0.01) 99\% confidence interval **, $(\mathrm{P}<0.05) 95 \%$ confidence interval * $(\mathrm{P}>0.05)$ below $95 \%$ confidence interval and not significant, $* *=$ Highly significant $*=$ Significant, NS $=$ Not significant.

Table 9: Base Exchange Index values.

\begin{tabular}{|c|c|c|c|c|c|c|c|c|c|}
\hline Parameters & Locality & $\mathbf{N A / K}$ & & $\mathrm{Mg} / \mathrm{Ca}$ & & $\begin{array}{c}\mathrm{Ca}+\mathrm{Mg} / \\
\mathrm{Na}+\mathrm{K}\end{array}$ & & BEI & \\
\hline $\begin{array}{c}\text { Spring } \\
\text { source/Village }\end{array}$ & $\begin{array}{c}\text { Sources of } \\
\text { basalt }\end{array}$ & January & July & January & July & January & July & January & July \\
\hline S2 & Mbei spring & 0.49 & 0.50 & 0.71 & 0.61 & 1.40 & 0.56 & 6.21 & 0.94 \\
\hline S3 & $\mathrm{Mbu}$ & 0.46 & 0.45 & 0.27 & 0.21 & 1.00 & 0.29 & 4.62 & 1.47 \\
\hline S4 & Ngabshi & 0.30 & 0.57 & 5.46 & 0.22 & 1.09 & 0.30 & -23.00 & -40.4 \\
\hline S6 & $\begin{array}{l}\text { Nkiedor } \\
\text { Sources of } \\
\text { trachytes }\end{array}$ & 0.40 & 0.45 & 4.70 & 40.46 & 1.13 & 0.84 & 1.22 & -4.6 \\
\hline S1 & Mbumatoh & 0.43 & 0.75 & 0.51 & 0.53 & 7.31 & 2.8 & -4.18 & -6.5 \\
\hline S5 & Mbawezang & 0.41 & 0.46 & 1.65 & 0.48 & 0.74 & 0.40 & -13.16 & -44.3 \\
\hline
\end{tabular}




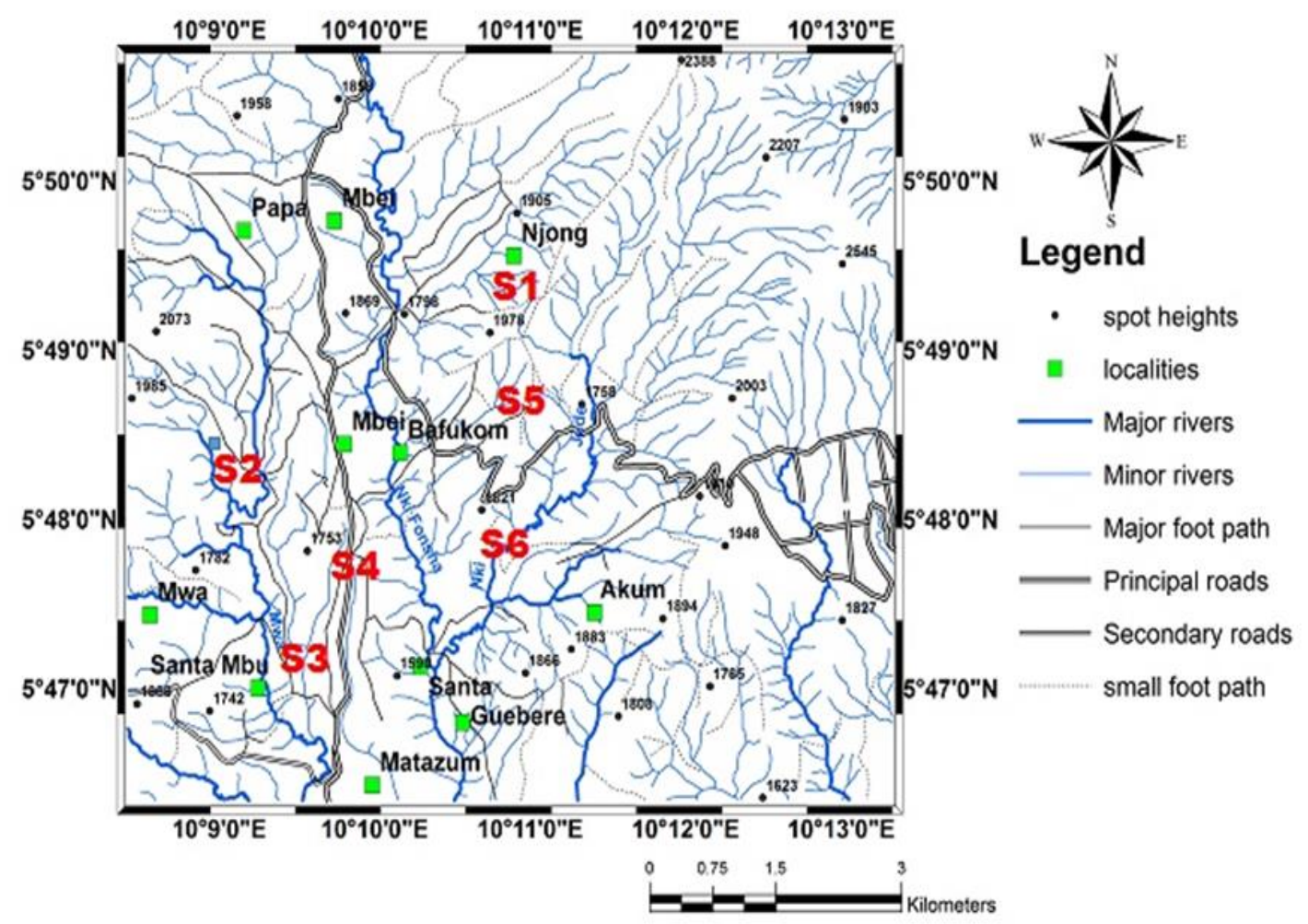

Figure 7: Map showing localities and where samples were collected from springs in the study area.

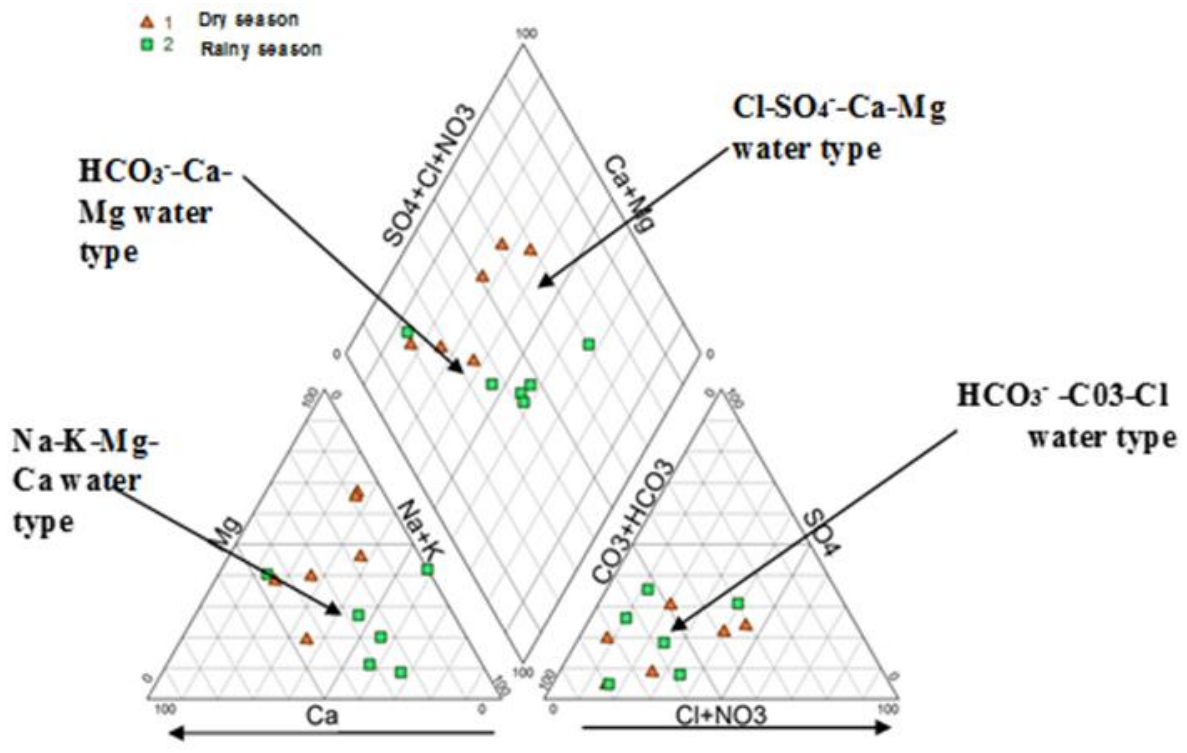

Figure 8: Position of water in the Piper's diagram. 


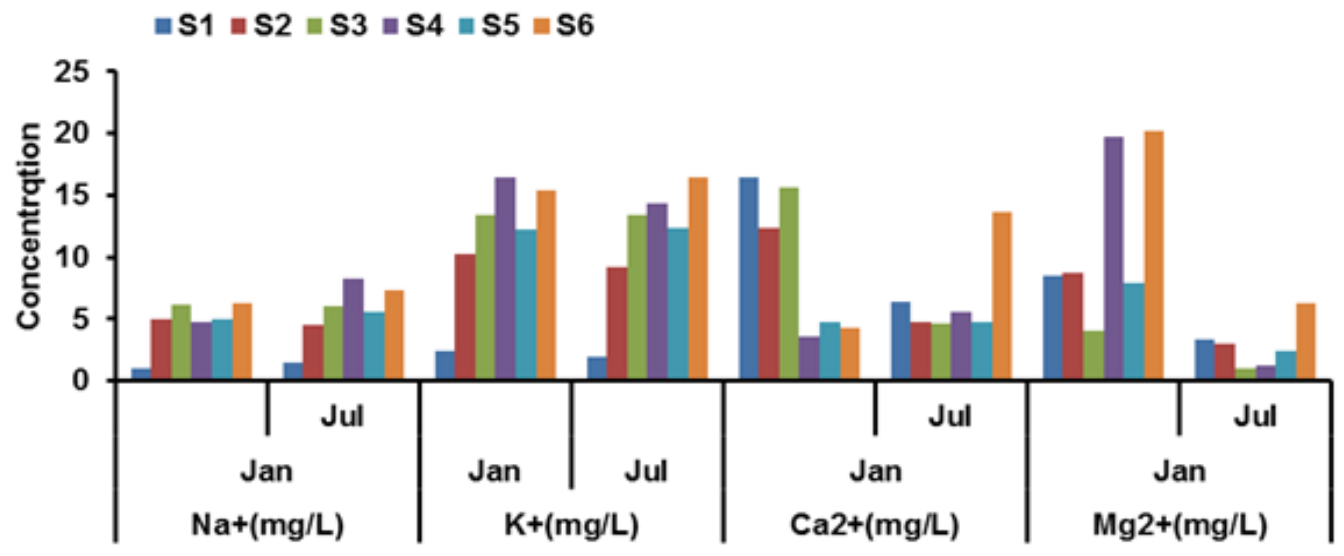

\section{Cations registered per Month}

Figure 9: Comparison in cations measured for the water samples.

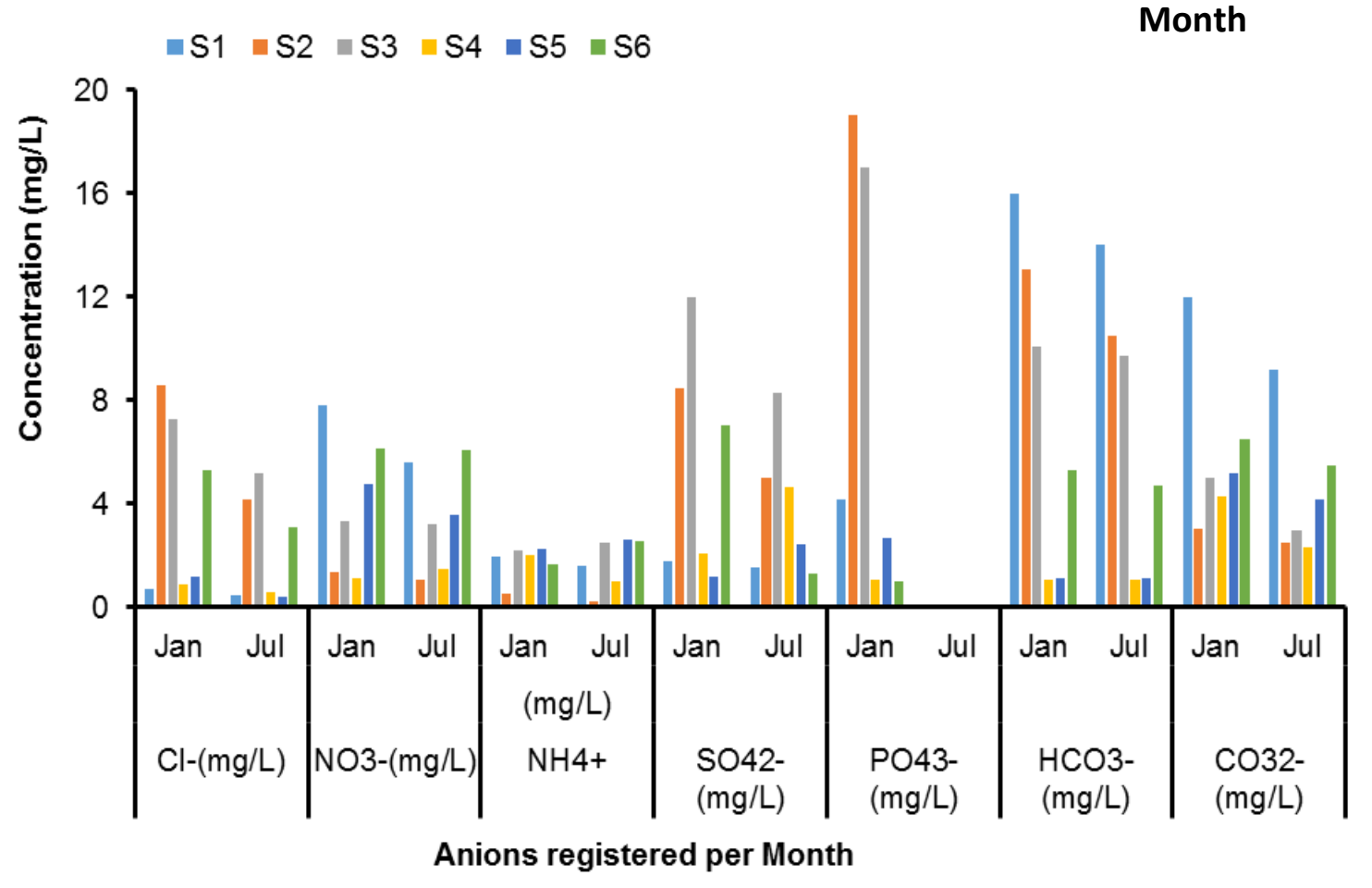

Figure 10: Comparison of anions in samples for the rainy and dry seasons. 


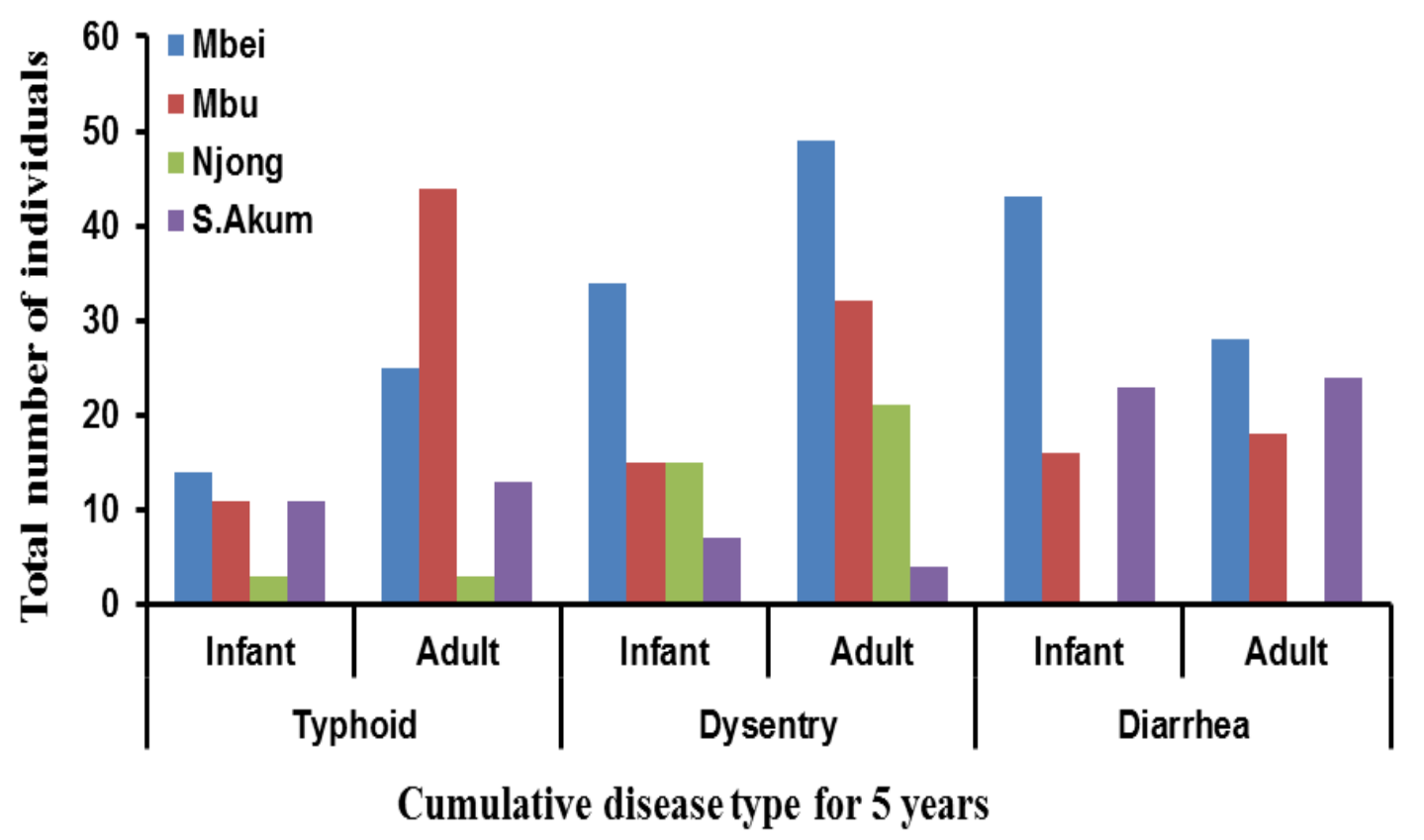

Figure 11: Cumulative disease type per village for 5 years.

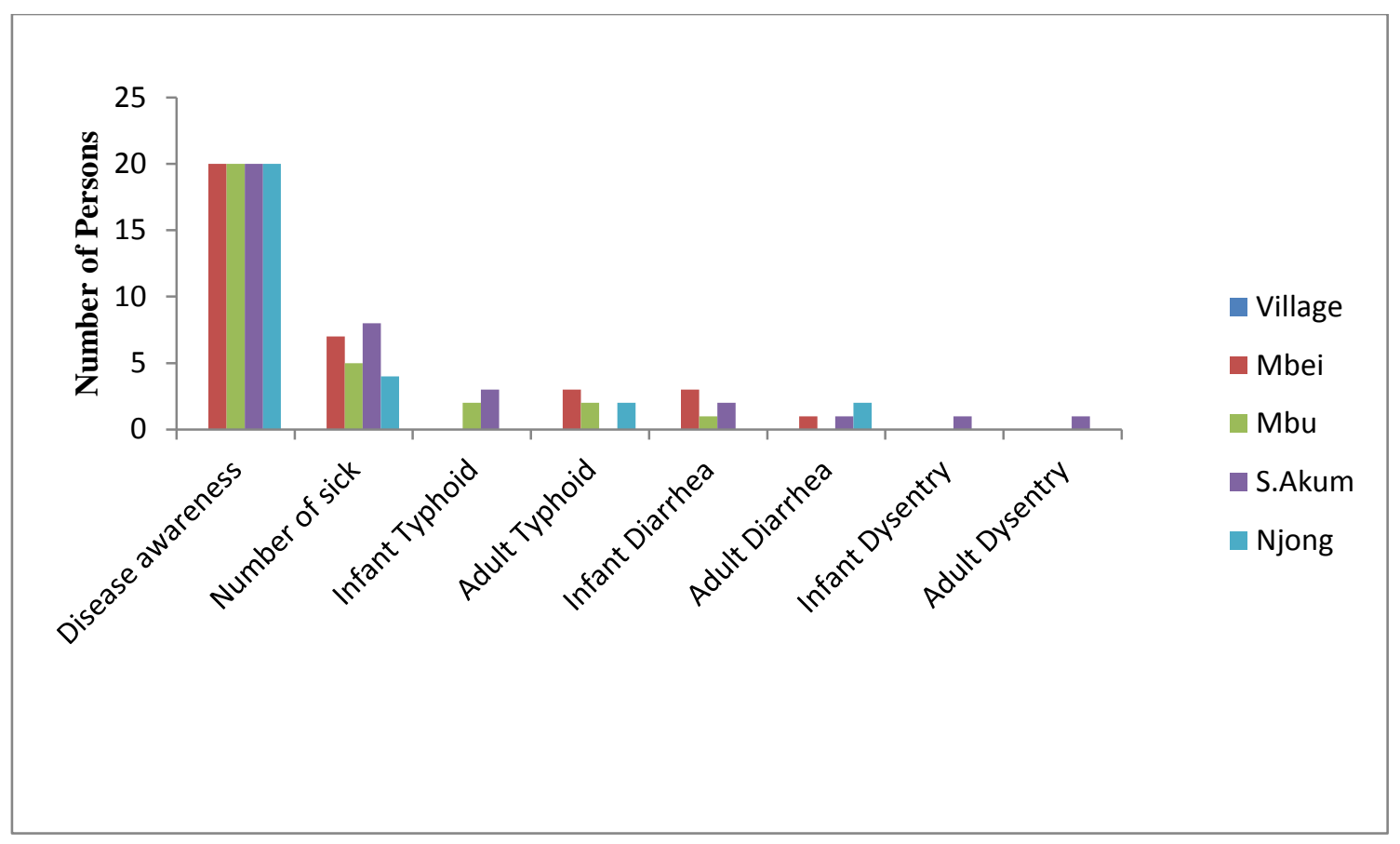

Figure 12: Questionnaires analysis. 

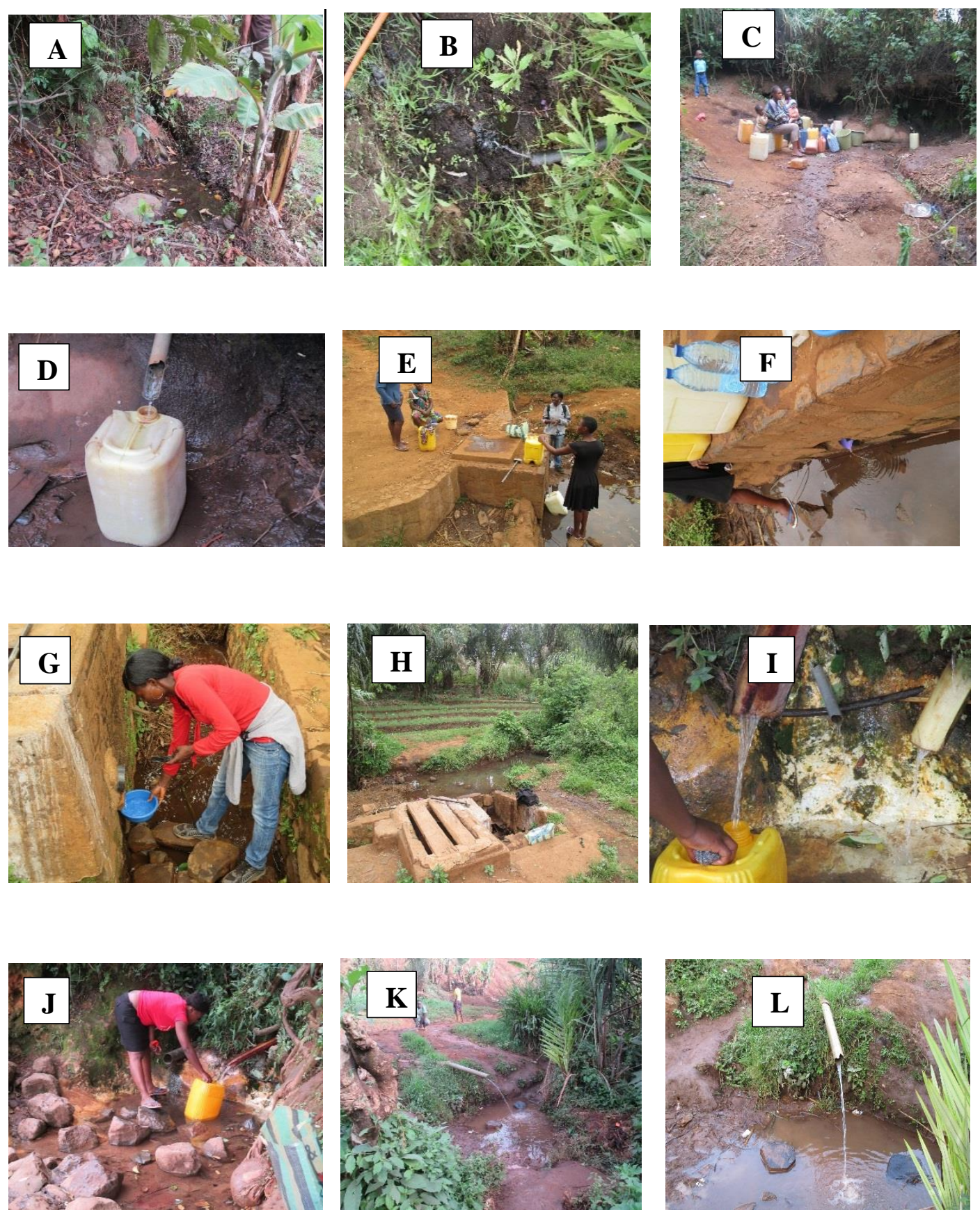

$\mathrm{A}=$ Mbumatoh spring showing water source while $\mathrm{B}$ shows the pipe collecting the water to the population.

$\mathrm{C}=$ Mbawezang spring showing population fetching water and $\mathrm{D}$ is showing the water source.

$\mathrm{E}=$ Ngabshi spring showing population fetching water and $\mathrm{F}$ is showing the source and surroundings.

$\mathrm{G}=$ Mbu spring showing collection of flow rate and $\mathrm{H}$ showing water source and surroundings.

$\mathrm{I}=$ Mbei spring showing water source and means of collection while $\mathrm{J}$ shows the surrounding and usage by population.

$\mathrm{K}=$ Nkiedor spring showing water usage by population and L showing water source and surroundings.

Figure 13: Showing various water sources and surroundings. 


\section{DISCUSSION}

The deep fracturation of the rocks of the study area linked the surface and the perched water table of the underground aquifer where water is then released to the surface already in contact with the rocks. The progressive weathering of these rocks released minerals within them which are altered by several processes like hydrolysis, hydration, and oxidation to release ions into water sources.

The brown color of the Mbumatoh and Nkiedor springs might have resulted from rainfall which collected and transported soil and sediments to the springs. The flow rates of the different springs were lower during the dry season and correspond to lower rainfall in the catchments and high evaporation in the watershed during this season. These flow rates increased during the rainy season due to an increase in rainfall and lower evaporation. The difference in the flow rate of these water sources during the different seasons indicated that discharge is greatly reduced in the dry season due to climatic conditions and low rainfall. Since all the springs flow in both seasons, they are permanent springs and can be considered a reliable source of water. The $\mathrm{pH}$ of the water sources were higher in the rainy season may be resulting from reduction in alkalinity due to heavy rainfall while in the dry season, $\mathrm{pH}$ was low probably due to increasing atmospheric temperatures.. The high acidity during the dry season may be due to production of $\mathrm{CO}_{2}$ from biological activities in the soil zone.

The high EC content in water sources during the rainy season may be due to altitude and topographic nature of the area and was lower during the dry season, perhaps due to dilution or shorter residence time for waterrock interaction in the aquifer before discharging into the springs while the high content of TDS in water sources may be due to the accumulation of salts in greater quantity in the dry season than in the rainy season where water infiltration will dilute the salts concentration. Similar results were obtained by Mfonka et al. (2015), indicating low mineralization of water within the aquifer
(Wirmvem et al., 2013a). Overall, the relatively high $\mathrm{EC}$ and $\mathrm{HCO}_{3}^{-}$values of Nkiedor spring was probably due to the intense anthropogenic activity and from organic sources such as decaying organisms (animals and plants).

The mineralization of springs probably originates from processes such as weathering, ion exchange processes, silicate dissolution, and anthropogenic activities, as maybe the case of Iron whose content is higher.

The $\mathrm{Ca}^{2+}$ dominance in the dry season might result from the presence of acid plagioclase $\left(\mathrm{CaAlSl}_{3} \mathrm{O}_{8}\right)$ serving as a source of mineralization in the formation. A similar study along the Cameroon volcanic line specifically the Sabga springs was carried out by (Chenyi, 2012). So the potential source could be the dissolution of silicate minerals probably biotite $\left(\mathrm{K}(\mathrm{MgFe})_{3}\left(\mathrm{AlSi}_{3}\right) \mathrm{O}_{10}(\mathrm{OH}\right.$, $\mathrm{F})_{2}$ ) and orthoclase $\left(\mathrm{KAlSi}_{3} \mathrm{O}_{8}\right)$. The presence of $\mathrm{Ca}^{2+}$ in the samples helps in building bones in young children which is an advantage to the inhabitants of Santa.

The abundance of $\mathrm{Ca}^{2+}$ ions may originate from the weathering of plagioclase, calco-sodic feldspaths and Anorthite (equation $1)$. The high content of $\mathrm{Mg}^{2+}$ could come from the dissolution of olivine (forsterite), serpentine, talc, magnesite, pyroxene, dolomite and $\mathrm{Mg}$-chlorite. $\mathrm{Mg}^{2+}$ in the water sources also helps in building bones in young children.

$\mathrm{CaAlSi}_{3} \mathrm{O}_{8}+2 \mathrm{CO}_{2}+3 \mathrm{H}_{2} \mathrm{O} \rightarrow \mathrm{Al}_{2} \mathrm{Si}_{2} \mathrm{O}_{5}(\mathrm{OH})_{4}$ $+2 \mathrm{HCO}_{3}^{-}+\mathrm{Ca}^{2+}$

Anorthite

Kaolinite

$\mathrm{Na}^{+}$and $\mathrm{K}^{+}$are soluble in water hence during the hydrolysis of minerals such as albite, gibbsite, kaolinite or smectite (Nabearing rock) through monosiallitisation and allitisation $\mathrm{Na}^{+}, \mathrm{K}^{+}$and $\mathrm{HCO}_{3}^{-}$are released in to solution and with some secondary minerals (Anazawa and Ohmori, 2005).

The low content of $\mathrm{Na}^{+}$in the water sources may result from the less abundance of Na-bearing rocks in the study area. Similar results were also obtained by Njoyim et al. (2016) in Babesi. The high sodium content in water sources is advantageous to the inhabitants since it is used for electrolyte 
balance in the body meanwhile a lower amount will not be profitable to the population. The common source of $\mathrm{Na}^{+}$may be from the dissolution of Albite as seen in equation (2) below.

$$
\begin{array}{r}
2 \mathrm{NASi}_{3} \mathrm{O}_{8}+2 \mathrm{H}^{+}+9 \mathrm{H}_{2} \mathrm{O} \rightarrow \mathrm{Al}_{2} \mathrm{Si}_{2} \mathrm{O}_{5} \\
(\mathrm{OH})_{4}+4 \mathrm{H}_{4} \mathrm{SiO}_{4}+2 \mathrm{Na}^{+}
\end{array}
$$$$
\text { Albite Kaolinite }
$$

The high concentrations of $\mathrm{K}^{+}$in water sources in the study area may be derived from fertilizer application. Alternatively, $\mathrm{K}^{+}$could also be sourced from rock silicate weathering with minerals as orthoclase, nepheline, leucite and biotite (equation 3) which also influences water quality through their concentrations (equation 3). The presence of $\mathrm{K}^{+}$and $\mathrm{Na}^{+}$also strengthens nervous connections.

$2 \mathrm{KAISi}_{3} \mathrm{O}_{8}+2 \mathrm{H}^{+}+9 \mathrm{H}_{2} \mathrm{O} \rightarrow \mathrm{Al}_{2} \mathrm{Si}_{2} \mathrm{O}_{5}(\mathrm{OH})_{4}$ $+4 \mathrm{H}_{4} \mathrm{SiO}_{4}+2 \mathrm{~K}^{+}$

\section{Orthoclase \\ Kaolinite}

The high concentration of iron $\left(\mathrm{Fe}^{2+}\right)$ in samples may be coming from hydrolysis of silicate minerals rich in iron. $\mathrm{Fe}^{2+}$ could enter into solution from the hydrolysis of silicate minerals rich in iron such as olivine, pyroxenes, biotites, augite, and magnetite in basalts and trachytes (equation 4 ).

$$
\begin{array}{cc}
2 \mathrm{KFe}_{3} \mathrm{AlSi}_{3} \mathrm{O}_{10}(\mathrm{OH})_{2} & +13 \mathrm{H}^{+}+\mathrm{CO}_{2}+2 \mathrm{H}_{2} \mathrm{O} \\
\mathrm{Al}_{2} \mathrm{Si}_{2} \mathrm{O}_{5}(\mathrm{OH})_{4}+2 \mathrm{~K}^{+}+ & 6 \mathrm{Fe}^{2+}+\mathrm{HCO}_{3}^{-} \quad \text { (4) } \\
\text { Biotite } & \text { Kaolinite }
\end{array}
$$

Excess of iron may lead to cardiac and liver diseases in adults. It may also lead to the rapid growth of bacteria in young children and diverse infections. The low concentrations of the rest of the heavy metals could be as a result of absence of rocks containing minerals with such elements. The presence of the $\mathrm{NH}_{4}{ }^{+}$in water sources may result from the solubility of nitrogenous fertilizers, bacteria, nitrogenous wastes on land and sewage (WHO, 2011).

The high bicarbonate concentrations in Mbumatoh, Mbei and Mbu water sources suggested natural sources like rock weathering and soil processes in the study area and the primary source may be the dissolved $\mathrm{CO}_{2}$ in rain but the decay of organic matter at the surface may also release $\mathrm{CO}_{2}$ for dissolution Thus, weathering, precipitation, and organic decay probably accounted for the dominance of the $\left(\mathrm{HCO}_{3}{ }^{-}\right)$ion in the water sources (equation 5).

$$
\mathrm{CO}_{2}+\mathrm{H}_{2} \mathrm{O} \rightarrow \mathrm{H}^{+}+\mathrm{HCO}_{3}^{-}
$$

The low concentrations of bicarbonates in Ngabshi, Mbawezang and Nkiedor may be due to gradual dissolution of ions. Therefore, the occurrence of bicarbonate ions in all the water sources is probably due to the alteration of plagioclase found in the rocks. The $\mathrm{HCO}_{3}{ }^{-}$ and $\mathrm{H}^{+}$may also increases the acidity of the water. The low concentrations of sulphate ions in the water sources could result from $\mathrm{SO}_{2}$ and $\mathrm{H}_{2} \mathrm{~S}$ dissolution, oxidation of anhydrite, gypsum, application of fertilizers and detergents (Jain et al., 2006; Abboudi et al., 2014). Excess of $\mathrm{SO}_{4}{ }^{2-}$ in water sources will lead to adverse health situations such as gastro-intestinal problems. The $\mathrm{NO}_{3}^{-}$ions resulted from the atmosphere, legumes, plant debris synthetic fertilizers such as Ammonia, ammonium nitrate and other nitrogenous compounds, and animal excrement. The low nitrate content in the water sources may be due to anthropogenic sources such as $\mathrm{NO}_{3}{ }^{-}$ fertilizers, sulphates and industrial effluents (Aiuppa et al., 2003; Jiang et al., 2009) and was similar to that from Sabga suggested by (Chenyi, 2012).

The low $\mathrm{Cl}^{-}$content in water sources may be due to lack of chlorination of the water sources therefore suggesting that $\mathrm{Cl}^{-}$ could come from the dissolution of minerals such as sodalite, apatite, feldspathoids, halite or precipitation. This also indicates a possible pollution from human sewage and animal manure (Hughes, 2004). The high $\mathrm{PO}_{4}{ }^{3-}$ content in water sources in the dry season could probably be resulting from organic matter decay from the numerous farmlands and fertilizer application (Mitra et al., 2007; Kannan and Sabu, 2009) meanwhile a drastic drop occurred in the rainy season may be due to the high rainfall causing high dissolution in water sources.

The positive values of BEI in Mbei and Mbu springs ( $>0)$ signifies exchange of ions in solution which may be due to the significant chlorine content in the water sources indicating exchange of $\mathrm{Na}^{+}$and $\mathrm{K}^{+}$ions in the water sources with $\mathrm{Ca}^{2+}$ and $\mathrm{Mg}^{2+}$ in 
argillaceous minerals thus indicating that the water is freshening (Schoeller, 1962). Also, the negative values of BEI in Mbumatoh, Ngabshi, Mbawezang and Nkiedor water sources could be signifying exchange of ions between alkali $\left(\mathrm{Na}^{+}\right.$and $\left.\mathrm{K}^{+}\right)$metals of clay minerals with alkaline Earth metals $\left(\mathrm{Ca}^{2+}\right.$ and $\mathrm{Mg}^{2+}$ ) of the water sources thus indicating salinization.

The correlation between $\mathrm{pH}$ and sodium, sulphate and nitrate could be due to their relationship implying that increased in $\mathrm{pH}$ will also affects the content of the other elements. The significant correlation between Temperature and sulphate also indicates that increased in Temperature will influence the concentration of sulphate. The highly significant content of phosphates in water sources gave a positive correlation with bacteria such as enterobacteria, Escherichia coli and Streptococcus suggesting that water sources with high alkalinity favours the growth of bacteria in water.

The Na-K-Mg water-type dominated in the study area for cations while the $\mathrm{Ca}$ $\mathrm{HCO}_{3}$ water type for anions also dominates indicating that the major ionic evolution in the aquifer is controlled by water-rock interactions (Jiang et al., 2009) whereas these water facies were very different from that obtained in Baya of Ivory coast by Germain et al. (2019).

The presence of bacteria in all water sources could be attributed to poor sanitation by humans and influx from runoffs. Thus the water sources were classified into categories B whereby the water could be treated and consumed and $\mathrm{C}$ which renders the water unfit for drinking. The high content of Enterobacteria, E.coli, and Streptococcus in all the water sources could be explained by its correlation with phosphate. Generally, bacteria play a positive role in the environment like aerating the soil but at the same time contaminate drinking water. Similar results were obtained by Njoyim et al. (2016) in Babesi as well as Burkina Faso, where untreated water had a greater number of bacteria than the treated water (Aminata et al., 2018).
From field observations and data from Santa District hospital, the high no of persons infected Mbei and Mbu villages had poor sanitation and this was reflected as inhabitants from these communities had the highest number of infected persons of typhoid, dysentery and diarrhoea both in adults and infants respectively. Also, the high no of adults infected in Njong village of diarrhoea and adults in Santa-Akum with dysentery may be due to lack of water and poor sanitation too. The prevalence of water borne diseases in the study area may be typical of fecal pellets in water especially in Mbei spring where a toilet is situated at about $10 \mathrm{~m}$ from the source. WHO standards aim for zero bacteria per $100 \mathrm{ml}$ but most of the water sources were contaminated.

\section{Conclusion}

This research work was aimed at evaluating the quality of spring water and its effects on human health since they depend on springs as their major source of drinking water. The progressive weathering of rocks in this area released minerals within them which were altered by several processes like hydrolysis, hydration, and oxidation to release ions into the water sources. The springs are generally clear, clean, odourless and colourless except for the Mbumatoh and Nkiedor springs which were not clear in July due to the influx of runoff from rainfall. The flow rates of water sources were higher in July than in January. Water sources were acidic to neutral falling partly within the WHO limits with some water sources being acidic. The springs indicated a wide range in Total dissolved solids, Electrical conductivity, turbidity, bicarbonates, phosphates, magnesium, calcium and potassium, and lesser amounts of sodium, ammonia, nitrate, and chloride which were within WHO specifications. Most of the cations and anions in this work were from rock alterations which contributed to the water chemistry. In most of the water sources, chlorine content was very low which means that they are scarcely disinfected. In all the cases, Mbei, Ngabshi, Mbu and Nkiedor springs were always the 
most contaminated water sources while Mbawezang and Mbumatoh springs were the least. These water sources were all contaminated by heavy metals and bacteria.

The presence of different species of bacteria in the water sources indicated animal and anthropogenic activities, as well as leaching from toilets around water sources. Also, the prevalence of waterborne diseases like typhoid fever, dysentery and diarrhea indicated contamination and therefore, the water sources need to be treated. The health implication of this polluted water to the community requires serious attention.

\section{COMPETING INTERESTS}

The authors declare that they have no competing interests.

\section{AUTHORS`CONTRIBUTIONS}

IKN carried out the field work, laboratory work and assembled the article. LK and JT supervised the research work at all stages. TMA and NEBT assisted in writing and editing of the work.

\section{ACKNOWLEDGMENTS}

The authors are grateful to the inhabitants of the study area and health authorities in Santa for providing the necessary information needed to accomplish this work. The authors are also grateful to the workers of the laboratory of Institut de Récherche Géologique Minières (IRGM), laboratory of Soil Analysis and Environmental Chemistry at the Faculty of Agronomy and Soil Sciences (FASA), Physiology/Microbiology Laboratory of the Department of Animal Production, FASA of the University of Dschang for carrying out the necessary analysis needed for this research work.

\section{REFERENCES}

Abboudi A, Tabyaoui H, El Hamichi F, Benaabidate L, Lahach A. 2014. Etude de la qualité physico-chimique et contamination métallique des eaux de surface du bassin versant de Guigou, Maroc. European Scientific Journal,
10:1857-7881.

DOI:

10.19044/esj.2018.v14n6p83.

Aiuppa A, Bellomoa S, Bruscab L, Alessandrolo WD, Federico C. 2003. Natural and anthropogenic factors affecting groundwater quality of an Active volcano (Mt. Etna, Italy). Applied Geochemistry, 18: 863-882. DOI: 10.1016/S0883-2927(02)00182-8.

Aminata K, Boubacar S, Almamy K, Jacques S, Paul S, Brigitte K, Lambert N, Dayéri D. 2018. Impact of chlorination on the microbiological quality of drinking water in school area: case study of Central North Region in Burkina Faso. International Journal of Biological and Chemical Sciences, 12(3): 1225-1233.

Anazawa K, Ohmori H. 2005. The hydrochemistry of surface waters in andesitic volcanic area, Norikura volcano, central Japan. Chemo-Sphere, 59: 605-615. DOI: http://dx.doi:org/10.1016/j.chemosphere. 2004.10.018.

Bohlke JK. 2002. Groundwater recharge and agricultural contamination.

Hydrogeology Journal, 10:153-179. DOI: 10.1007/s10040-001-0183-3.

Cheesbrough M. 2000. Medical Laboratory Manual for Tropical Countries Volume II: Microbiology, Tropical Health Technology. Doddington : New York.

Chenyi MV. 2012. Volcanism and hydrochemistry of thermal and mineral springs in the Bambui-Sabga area (North-West Region). Master's thesis, University of Bamenda, Bamenda, p. 75.

Fantong WY, Satake H, Ayonghe SN, Aka FT, Asai K. 2009. Hydrogeochemical controls and usability of groundwater in semi-arid Mayo Tsanaga River Basin, Far-North Cameroon. Environ. Geol., 58(6): 1281-1293. DOI:10.1007/s00254008-1629-x.

Germain KNG, Jules MOM, Narcisse KA, Aristide GD et Lanciné DG. 2019. Caractérisation hydrogéochimique des eaux souterraines du bassin versant de la Baya, Est Côte d'Ivoire. International Journal of Biological and Chemical 
Sciences, $\quad 13(1)$ : DOI:

https://dx.doi.org/10.4314/ijbcs.v13i1.44

Hughes D, Philippe D Leener. 2004. Agriculture. African Rural Communities, 1(2): 125-153.

INS. 2008. Annuaire Statistique du Cameroun 2007. Institut National de Statistique, Direction Nationale de la Statistique et de la Comptabilité Nationale. Ministère de l'Economie et des Finances, novembre 2007.

Jain P Sharma, JD, Sohu D, Sharma P. 2005. Chemical Analysis of Drinking water in the villages of Sanganer Tehsil, Jaipur District. International Journal of Environmental Science and Technology, 2: 373-379. DOI: 10.4236/jep.2011.25071.

Jiang Y, Wu Y, Groves C, Yuan D, Kambesis P. 2009. Natural and Anthropogenic Factors Affecting the Groundwater Quality in the Nandong Karst Underground River System in Yunan, China. Journal of Contaminant Hydrology, 109(1-4): 49-61. DOI: 10.1016/j.jconhyd.2009.08.001.

Kamgang P. 2003. Pétrologie et géochimie d'un secteur clé de la ligne du Cameroun; les monts Bamenda; implication sur la genèse et l'évolution des magmas. Thèse de Doctorat d'Etat, Université de Yaoundé I, Yaoundé.

Kamgang P, Njonfang E, Nono A, Gountie D, Tchoua F. 2010. Petrogenesis of a silicic magma system: Geochemical evidence from Bamenda Mountains, NW Cameroon, Cameroon Volcanic Line. J. Afr. Earth Sci., Geoscience, 341(12): 645-654. DOI: 10.1016/j.jafrearsci.2010.03.008.

Kannan N, Sabu J. 2009. Quality of Groundwater in the Shallow Aquifers of a Paddy Dominated Agricultural River Basin, Kerala, India. World Academy of Science, Engineering and Technology, 52: 475-493. DOI: 10.4236/ce.2012.34079 7,410.

Kresic N. 2007. Hydrogeology and Groundwater Modelling ( $2^{\text {nd }}$ edn).
Taylor and Francis Group, CRC press, LLC, Boca Raton: Florida.

Kengni L, Simo PJ, Temgoua E, Tematio P, Ndam NJR, Boeglin JL. 2013. Hydrogeochemical processes in the southern slope of the Bambouto Mountain West- Cameroon. International Journal of Biological and Chemical Sciences, 7(3): 898-899. DOI: 10.4314/ijbcs.v7i3.17.

Li LP, Byleveld A, Smith W. 2009. Assessment of chemical quality of drinking water. In Drinking Water Quality Assessment. Tetova Region Science publication: Tetova.

Magha A. 2003. Evaluation of the Santa intervillage water project, (North West Region) Master's thesis, University of Dschang, Dschang, p. 6-10.

Mfonka Z, Ndam Ngoupayou JR, Ndjigui PD, Zammouri M, Kpoumie A, Rasolomanana E. 2015. Hydrochimie et potabilité des eaux du bassin versant du Nchi dans le plateau Bamoun (Ouest Cameroun). International Journal of Biological and Chemical Sciences, 9(4): 2200-2218.

DOI: http://dx.doi.org/10.4314/ijbcs.v9i4.39.

Mitra BK, Sasaki C, Enari K, Matsuyama N, Fujita M. 2007. Suitability Assessment of Shallow Groundwater for Agriculture in Sand Dune Area of Northwest Honshu Island, Japan. Applied Ecology and Environmental Research, 5 (1): 117-188. DOI:10.1111/j.1540-6237.2007.00500.x.

Njoyim EBT, Biosengazeh NF, Alakeh MN, Tameu DY. 2016. Quality control of domestic water in Babessi village in North West in Cameroon. International Journal of Biological and Chemical Sciences, 10(3): 1382-1402.

Piper AM. 1953. A graphic procedure in the geochemical interpretation of wateranalyses. Eos, Transactions American Geophysical Union, 25(6): 914-928. DOI: 10.4236/ijg.2012.32039 4,941.

Provencher SK, Grasby S, Mayer B. 2010. Assessment of Water-Rock Interactions in the Upper Bow River Basin using Chemical and Isotopic Parameters for 
Surface Water and Groundwater Samples. GeoCanada. DOI: 10.1016/j.proeps.2013.03.206.

Stocks ME, Ogden S, Haddad D, Addiss DG, McGuire C, Freeman MC. 2014. Effect of water, sanitation, and hygiene on the prevention of trachoma: a systematic review and meta-analysis. PLoS Med., 11(2): 1-29. DOI: 10.1371/journal.pmed.1001605.

Strunz EC, Addiss DG, Stocks ME, Ogden S, Utzinger J, Freeman MC. 2014. Water, sanitation, hygiene, and soil-transmitted helminthic infection: a systematic review and meta-analysis. PLoS Med., 11(3): 138.

DOI:

10.1371/journal.pmed.1001620.

UNEP. 2006. Water Quality for Ecosystem and Human Health. United Nations Environment Program/Global Environment Monitoring System (UNEP/GEMS) Program. 1-132.

WHO. 2011. Guidelines for Drinking-Water Quality $\left(4^{\text {th }}\right.$ edn). WHO Library Cataloguing-in-Publication Data.

WHO. 2014. Water pollution. http://www.explainthatsttuff.com/waterp ollution.html.
Wirmvem MJ, Takeshi O, Fantong WY, Ayonghe SN, Suila JY, Asobo NEA, Tanyileke G, Joseph VH. 2013a. Hydrochemistry of shallow groundwater and surface water in the Ndop plain, North West Cameroon. African Journal of Environmental Science and Technology, 7(6): 518-530. DOI: 10.5897/AJEST2013.1456.

Wirmvem MJ, Fantong WY, Wotany ER, Takeshi O, Ayonghe S N. 2013b. Sources of bacteriological contamination of shallow groundwater and health effects in Ndop plain, Northwest Cameroon. Journal of Environmental Science and Water Resources, 2(4): 127 - 132. DOI: 10.5897/AJEST2013.1456.

Yidana SM, Ophori D, Banoeng Y. 2008. A Multivariate statistical analysis of surface water chemistry data- the Ankobra Basin, Ghana. Journal of Environmental Management, 86: 80-87. DOI: 10.1016/j.jenvman.2006.11.023. 